Article

\title{
The Living Lab as a Tool to Promote Residents' Participation in Destination Governance
}

\author{
Hannes Thees *(D), Harald Pechlaner, Natalie Olbrich and Arne Schuhbert \\ Chair of Tourism, Center for Entrepreneurship, Catholic University of Eichstaett-Ingolstadt, 85072 Eichstätt, \\ Germany; harald.pechlaner@ku.de (H.P.); natalie.olbrich@ku.de (N.O.); arne_schuhbert@yahoo.de (A.S.) \\ * Correspondence: hannes.thees@ku.de
}

Received: 15 November 2019; Accepted: 27 January 2020; Published: 4 February 2020

\begin{abstract}
Growing numbers of tourist arrivals, in combination with community-centered tourism products, have fueled the recent debate on overtourism and a redefining of local steering processes. This has also called for the participation of residents in governance processes. One tool to utilize residents' participation and cross-stakeholder involvement is the Living Lab (LL), which also functions as a medium for self-organization. This article tackles the research gap that exists in the combination of the LL mechanisms and destination governance (DG). Therefore, the research questions address the characteristics and mechanisms of LLs and the potential for residents' participation. These efforts are operationalized through a systematic literature review (SLR) on LLs, which involves 40 articles. The transfer of the LL characteristics towards DG reveals that certain drivers and barriers exist when implementing the LL in the governance process, such as the combination of destination and city planning or the redefining of hierarchical structures. The SLR recommendations for future research are based on the interface of LL and DG.
\end{abstract}

Keywords: Living Lab; destination governance; stakeholders; residents' participation; overtourism; systematic literature review

\section{Introduction: The Role of Residents in Destinations}

The discourse on overtourism has recently stressed, inter alia, the importance of residents' participation in tourism development [1]. Overtourism has manifested as a subjective perception of "too much" tourism at a certain place at a certain time, which is not limited to objective quantitative statistics, such as tourism intensity [2], but opens up discussions about the quality of local tourism development. Against the background of nearly unregulated tourism growth, tourism managers, service providers, and officials face local protests and demand for regulation. The handling of overtourism requires a widespread discourse that involves many different perspectives, such as the discussion about overloading of infrastructure for tourists and residents [3], sociocultural changes [4], or the tourism gentrification of certain districts [5]. Through different studies, it becomes obvious that urban development, especially, is a strategic issue not only for urban planners or tourism managers, but also for tourists and residents [5]. In particular, residents and the host community, due to their cultural heritage, are important for distinguishing a place from other destinations [6]. Although it is acknowledged that residents represent a stakeholder group in tourism, they are still underrepresented in planning processes and possibly do not receive the necessary attention of tourism planners [7]. This is also true of the exploration of the concrete interests of residents in local tourism and their motivation to demonstrate against it. Investigation into their interests calls for a revision of stakeholder participation in destination governance (DG). The degree to which residents are involved in decision-making processes also needs to meet the objectives of a certain destination planning [8-11]. Sustainable development or innovation-driven concepts, especially, necessitate a high involvement of 
the local community [12,13], which in turn addresses a relational governance and the development of organic networks [14]. The importance of governance results theoretically from its role in shaping the substance and form of destination networks and politically from the promise to bring principles such as self-guidance, cooperation, dialogue, coordination, participation, and equality to life [15-20]. However, the recent protests against tourism development illustrate that there might be a deficit in terms of practically applying those principles and mechanisms, as Amore and Hall (2016) [21] pointed out for the way governance is structured and applied.

To condense the problem statement, overtourism is not only a mere tourism issue [5]; instead, DG needs to be considered interdependent on community development, which is based on self-governance [22] and an active cross-stakeholder approach [23]. Tools for residents' participation could be sourced in related concepts, such as participatory planning and cooperative or participatory design [24]. One interesting tool to utilize those approaches is the Living Lab (LL), which has been applied for discussing, inter alia, urban and rural mobility, politics, architecture, and the green economy. The LL can be a successful tool for managing cross-stakeholder issues, and this is supported by several studies (see Section 4). Still, a gap exists in the application of the LL in the destination context [25]. This paper involves the assumption that the LL might be a useful tool in DG as well by bringing all kinds of stakeholders together to discuss concrete development issues in a flexible and innovative setting. The LL therefore functions as a medium for self-organization in knowledge conversion and innovation [26-29].

Within this framework (Figure 1), this paper tackles two key questions: (1) What are the characteristics and mechanisms of Living Labs (LLs)? and (2) How can the LL be utilized to promote the participation of residents in the context of destination governance (DG)? To answer these questions, we present the theoretical background of the study, which recapitulates the well-researched requirements of DG and residents' participation (Section 2). This is followed by a systematic literature review (Sections 3 and 4), which aims to identify the characteristics of LLs, which are seldom reviewed in a systematic manner. Based on this, we explore the interface of the LL approach and DG (Section 5). The outcomes suggest research recommendation and hint at the practical implementation of the LL in the specific context of DG. The research is assigned to a community-based destination-on either a rural or an urban scale.

\begin{tabular}{|c|c|c|}
\hline \multirow{6}{*}{$\begin{array}{l}\text { LIVING LAB } \\
\text { - Participatory approach for } \\
\text { managing cross-stakeholder } \\
\text { issues, including residents } \\
\text { - Application in regional and } \\
\text { urban studies } \\
\text { * Gap: Systematic exploration of } \\
\text { characteristics and mechanisms }\end{array}$} & & DESTINATION GOVERNANCE \\
\hline & \multirow{5}{*}{$\begin{array}{l}\text { Gap: Application of the LL } \\
\text { in destinations } \\
\text { * Gap: Commonalities and } \\
\text { dichotomies } \\
\text { * Gap: Barriers in applying the } \\
\text { LL in DG }\end{array}$} & - System of hard and soft steering \\
\hline & & $\begin{array}{l}\text { mechanisms } \\
\text { - Extended research and systematic }\end{array}$ \\
\hline & & literature reviews available \\
\hline & & $\begin{array}{l}\text { - Criteria for residents participation } \\
\text { - Residents underrepresented in } \\
\text { planning processes }\end{array}$ \\
\hline & & $\begin{array}{l}\text { - Revision of stakeholder } \\
\text { participation needed, especially on }\end{array}$ \\
\hline $\begin{array}{c}\text { Systematic literature } \\
\text { review } \\
\downarrow\end{array}$ & $\begin{array}{l}\text { Matching of characteristics and } \\
\text { mechanisms of LL and DG }\end{array}$ & $\begin{array}{l}\text { the role of residents } \\
\text { Lack in practically applying DG } \\
\text { principles and mechanisms }\end{array}$ \\
\hline $\begin{array}{l}\text { (1) Which are the characteristics and } \\
\text { mechanisms of Living Labs (LLs)? }\end{array}$ & \multicolumn{2}{|c|}{$\begin{array}{l}\text { (2) How can the LL be utilized to promote the participation of residents in the } \\
\text { context of destination governance (DG)? }\end{array}$} \\
\hline
\end{tabular}

Figure 1. Research Framework. Source: Own elaboration.

\section{Theoretical Background: Residents' Participation in Destination Governance}

The following section introduces the setting for residents' participation within DG. Finally, the methods and tools within DG are presented, focusing especially on the LL. 


\subsection{Participation in Times of Transformation}

Recently, governance has increasingly discussed the notion of sustainable development or sustainable tourism [30-34], which emphasizes a sustainability transition [35]. This focuses on global transformation processes that are also influenced by uncertainties and therefore require an adequate form of destination planning [36]. Such uncertainties evolve, for example, in global value chains and power asymmetries [37,38], in infrastructure development [39], in environmental issues and entrepreneurship [40], in travel participation [41], or in mobility transition [35]. In line with the sustainability discussion, the concepts of regionality and local space governance have gained great attention lately [42,43]. However, it is crucial that DG sources ideas and innovation from a variety of stakeholders and thus balances structural top-down approaches with bottom-up approaches [44,45]. Often this is referred to as good or effective governance, which enables local participation by providing a forum for information sharing, knowledge exchange, and discussion [31,46].

Residents' participation, which is embedded in the research stream on community participation, originally followed the modernization theory and later the dependency theory [47]. Participation can be described as a process in which people who are affected by a certain institution, environment, or program are in charge of decision-making [48-50]. Given a democratic system or any other system in a different area of life, governance structures can either promote or inhibit participation in decision-making. The handling of such governance and thus coordination mechanisms and power distribution within a value chain finds an equilibrium in the relational governance type, which includes a lead firm and numerous suppliers [22]. In addition, participation is also a process of distributing power and interests-in this case, the empowerment of residents in planning. In the context of destinations, empowerment must also include the implementation and decision-making process of tourism plans $[48,49]$. Although the target of participation is clear, the process of multi-stakeholder participation is rather complex and has induced various forms and graduations of participation [10,51]. To discuss residents' participation against the background of DG, further theoretical considerations are needed.

\subsection{Principles of Destination Governance}

Destination planning is interrelated with several dimensions such as management, marketing, leadership, entrepreneurship, and governance [52,53]. Within these dimensions, DG stands for a system-specific coordination, which enables the sharing and development of resources by the targeted stimulation of cooperation between independent service providers [16]. In a broad sense, DG builds upon a spectrum of mechanisms of control and stimulation whose individual composition and application in a specific development context strives for an implementation of effective management systems [54]. The importance of DG is visualized in its application at the network level, especially in community-based destinations, which depend on networking and proactive engagement [55]. The objective of DG is to enable a (formal or informal) coordination of inter-organizational resource exchange processes and to consequently create structural conditions for the networking of the actors within the strategic network to pursue common goals [56,57]. It is also the task of DG to create an institutional context for cooperation [16]. This is pursued through the optimization of structures and processes of the networks, due to routines in resource sharing and institutionalization $[17,58]$. In more detail, DG describes the sum of regulative processes and structures between public and private institutions as a collective problem solution, which is based on a shared sense and action orientation within a value and normative consensus [19].

The research on DG can be rooted, for example, in corporate management or political science [44], while a majority of governance studies in tourism applies an exploratory, social constructionist perspective [46]. In line with these two domains, Ruhanen et al. (2010) [44] identified a set of key elements and dimensions of governance within a literature review. However, they also acknowledge that the governance literature is "broad in scope but lacks cohesion, depth and strong theoretical underpinnings" [44]. Beaumont et al. (2010) [46] highlight the strong network focus within governance 
research and the question of how different network arrangements work in communication, knowledge diffusion, or trust. In direct relation to a local DG, they developed three network types: a council-led network governance structure, a participant-led community network governance structure, and a local tourism organization-led industry network governance structure [46].

As manifold types of governance and network configurations exist, they provide a suitable pool for implementing different innovation strategies, as community-based destinations are too diverse and flexible in their characteristics to apply a "one-fits-all" approach [19,22]. Based on the previous explanations, the implementation of effective DG systems has manifold variables. One of them relates to the stakeholders of the destination and their number, types, interests, or power constellations [59]. Thereby, any individual or group that is able to affect or which is affected by the performance of a corporation is a stakeholder [60]. In a community destination, in the sense of a strategic network configuration, stakeholders are the driving force of DG $[59,61]$. While several authors remain vague about who exactly a stakeholder is [62], Franch et al. (2010) explore three categories of stakeholders with primary or secondary roles in destination development: (1) local community, (2) big companies and external investors, and (3) municipalities and central government bodies. They further on concretize the stakeholder by highlighting the role of the destination management organization (DMO) [63-65], the hotel and cable car sector, cultural institutions and attractions, and guides or event managers. Moreover, every stakeholder can act as an institution or as a person (representative of the institution) [65]. As Komppula (2016) [62] summarizes stakeholder studies [63,64], it becomes obvious that stakeholder theory and stakeholder relationship management are central concepts for identifying the stakeholders of a destination. Although the local community is listed as a stakeholder group, it remains questionable whether all residents with their different interests are relevant stakeholders.

In order to organize the togetherness and, moreover, the cooperation of stakeholders with their different interests [62], several governance principles or guidelines are necessary. Most principles of governance reduce control, predictability, self-evident leadership, or given hierarchies (Breda et al., 2006). Instead, the normative basis of DG consists of values such as self-organization, cooperation, dialogue, participation, and equality [15-17,66]. Nonetheless, not all types of governance provide hierarchy-free structures and self-organization [22]. On a subordinated level, further factors assist the implementation of governance principles towards a joint goal, such as coordination [67], common development of an own identity, trustworthy, public welfare orientation, willingness to negotiate [16], and transparency [68]. The implementation of the mentioned principles in destinations and thus in a cross-stakeholder setting requires in particular a consensus on values and norms, which are embedded in geographical locations [22,51]. Several categorizations have been used to identify the most relevant dimensions of governance. Ruhanen et al. (2010) identified 40 governance dimensions through a comprehensive literature review. The seven most often referred dimensions are (1) accountability, (2) transparency, (3) involvement, (4) structure, (5) effectiveness, (6) power, and (7) efficiency [44]. A more precise set of governance dimensions has been delivered by Graham et al. (2010) [69], as shown in Figure 2. Figure 2 summarizes the aforementioned characteristics on DG in a brief manner, by illustrating its wide-ranging dimensions, where each factor is worth analyzing in depth. Figure 2 should serve as a guideline on certain dimensions that are also interrelated. The arrow on the right hand side therefore reflects how tools and principles assist to reach the targets of DG and possibly meet the motives of the stakeholders. However, the steering mechanism of DG in a relational approach is the starting point to debate the special role of residents. 


\begin{tabular}{|c|c|c|c|c|}
\hline \multicolumn{5}{|c|}{ DESTINATION GOVERNANCE } \\
\hline (A) Spaces & $\begin{array}{l}\text { 1. Living space } \\
\text { 2. Destination }\end{array}$ & $\begin{array}{l}\text { 3. Markets } \\
\text { 4. Company }\end{array}$ & $\begin{array}{l}\text { 5. Working place } \\
6 . \text { Economic regior }\end{array}$ & \\
\hline (B) Stakeholders & $\begin{array}{ll}\text { 1. } & \text { Local comm } \\
\text { 2. } & \text { Tourism ser } \\
\text { 3. } & \text { Related indu } \\
\text { 4. } & \text { Tourists }\end{array}$ & $\begin{array}{l}\text { roviders } \\
\text { and suppliers }\end{array}$ & $\begin{array}{l}\text { 5. Education } \\
\text { 6. Infrastructure and attra } \\
\text { 7. Big companies and exte } \\
\text { 8. Municipalities and cen }\end{array}$ & $\begin{array}{l}\text { ons } \\
\text { al investors } \\
\text { government bodies }\end{array}$ \\
\hline (C) Motives & 1. Leisure seekin & 2. Profit orien & 3. Public welfare & 4. Development \\
\hline (D) Targets & 1. Coordination & operation & 2. Identity development & 3. Innovation \\
\hline (E) Principles & $\begin{array}{l}\text { 1. Public partici } \\
\text { 2. Consensus or } \\
\text { 3. Strategic visi } \\
\text { 4. Responsiven } \\
\text { 5. Effectiveness }\end{array}$ & stakeholders & $\begin{array}{l}\text { 6. Efficiency } \\
\text { 7. Accountability to the } p \\
\text { 8. Transparency } \\
\text { 9. Equity } \\
\text { 10. Rule of law }\end{array}$ & lic and stakeholders \\
\hline (F) Tools & $\begin{array}{l}\text { 1. Guidelines anc } \\
\text { 2. Communicatio } \\
\text { 3. Cooperation ar }\end{array}$ & $\begin{array}{l}\text { fications } \\
\text { puping }\end{array}$ & $\begin{array}{l}\text { 4. Knowledge trans } \\
5 \text {. Meetings } \\
\text { 6. Tourism type }\end{array}$ & \\
\hline
\end{tabular}

Figure 2. Characteristics of Destination Governance (DG). Source: Own elaboration based on the findings mentioned above.

\subsection{Residents' Participation in Destination Development}

The subsequent section aims to define criteria of a DG that could assist in the successful participation of residents. A successful and sustainable destination development [70] relies more and more on an effective DG, which involves the residents of a destination $[1,16,69,71]$. In opposition to other stakeholder groups that often pursue the motive of profit orientation, residents who do not benefit in the first instance from tourism aim at maintaining or even improving their living conditions [72,73]. This dilemma is also the subject of the discussion on positive and negative externalities, which can be either compensated for or exhausted through networks (for urban networks, e.g., [74]). Due to the current overtourism debate, the role of residents in tourism development has gained attention because, without the support and acceptance of the residents, tourism to a destination will hardly be able to achieve a sustainable and quality-driven development $[7,75,76]$. This is all the more true as tourists are searching for intensive contact with locals and their traditions [77-79], while the locals may not be amenable or they even inhibit these contacts. Therefore, different authors request a consensus in DG that is also based on a certain degree of "mutuality" or "locality" $[70,80,81]$. What does the appropriate participation of residents look like?

Building on the discussion of participatory tourism in developed countries [9], many empirical studies concerning the role of residents in tourism development follow the social exchange theory in order to define factors that influence resident support [75,80,82]. Surprisingly, only a few studies have applied qualitative and mixed-methods approaches [73], although residents' attitude and involvement are highly subjective $[80,83-86]$. Besides this limitation, studies on residents' attitudes broadly agree that residents' support depends on the perceived tourism benefits for the community $[75,87,88]$. Against this background, residents' participation also becomes an issue of reality construction, socialization theory, and communication.

Still, certain research gaps when discussing residents' participation in tourism have been identified, although participatory approaches have a long history in developing countries [12] or in urban planning [89]. Boley et al. (2014) pointed out that studies have indeed proved the importance of economic benefits for residents, but that there is a need to include both economic and noneconomic 
factors in the discussion [82]. In addition, Komppula (2016) remarks that research on the role of residents in development issues is missing [62]. One study that explores this gap is that by Lee (2013) [88]. He researched different criteria to assess the support of residents in sustainable tourism development by utilizing the concepts of community attachment, community involvement, perceived benefits, perceived costs, and support for sustainable tourism development. The two most relevant concepts to influence residents' support are community involvement and community attachment. Community involvement describes the extent "to which residents are involved in sharing issues about their lives with their communities" [88]. In addition to that, community attachment [90] can be defined as the "individual's social participation and integration into community life and reflects an affective bond or emotional link between an individual and a specific community" [88]. As Vargas-Sánchez et al. (2015) conclude, there are many studies on community attachment, but only a few destinations link a positive attachment with the residents' attitude in development issues $[72,88,90]$. This is especially relevant for the overtourism debate in discussing the future of tourism by finding a consensus, which either strengthens the commitment on tourism development or refuses efforts to attract tourists.

Conversely, there are also studies that prove that a positive attachment can result in a negative attitude in tourism development [72]. In more detail, there is a whole set of variables that influence the residents' attitude for tourism development, such as the duration of residency [85], the status of destination development [72], political trust [62], the role of power [80,82], and the prevalent tourism form. For example, community-based tourism (CBT), especially, promises to empower host communities in terms of development and defines governance as a key concept [12]. Although DG can provide a broad framework for involving local residents, it still needs further concretization on an operational level.

\subsection{Tools for Residents' Participation}

Against the background of the theoretical considerations on the residents' role in destination development, a question arises: Which tools or methods are applied in DG to achieve the participation of different stakeholder groups?

Based on the governance principles (Figure 2), a whole set of tools for participation can be compiled (Table 1). It must be said that this compilation is sourced from different publications and different scientific domains, which is also caused by blurring the borders between DG, policy, and management. The implementation of such tools can be oriented on innovation processes that also mix tools of great variability and tools for structuring and organization. Dimensions, such as guidelines and certifications, communications, and knowledge transfer, can structure those soft tools and provide practical guidance for governance implementation. It is important to note that the implementation of a diversity of tools is the key to pursue the targets of DG, not just a single tool. However, the authors would like to focus on tools that address more than one stakeholder group. In addition, we believe that involvement—of residents or other stakeholders-is easier and more fruitful if a concrete topic or new ideas are discussed. This is especially true for tools such as future labs, open spaces, portals, future scenarios, seminars, and workshops. Moreover, theory consistently indicates that the best conditions for transferring (especially tacit) knowledge are those of personal contact [91,92] and thus require a sufficient community attachment and joint knowledge base [90]. The same is true for cooperation, which has been successful in tourism for implementing meetings or so-called "round tables" [93,94]. 
Table 1. Tools for DG.

\begin{tabular}{|c|c|c|}
\hline Guidelines and Certifications & Communication & Cooperation and Grouping \\
\hline 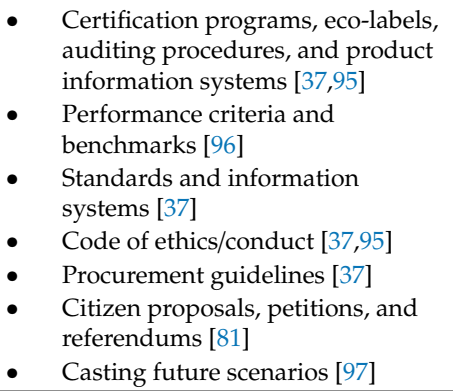 & 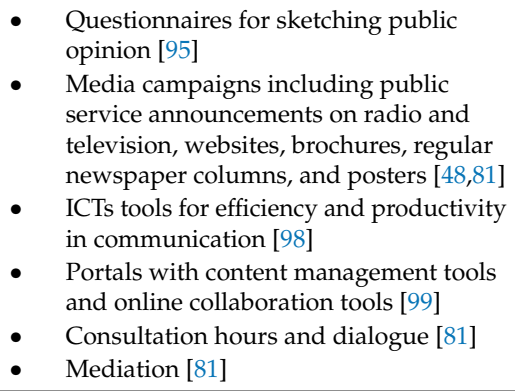 & $\begin{array}{ll}\text { - } & \text { Partnership agreements [95] } \\
\text { - } & \text { Network analysis and mapping of } \\
\text { - } & \text { Multi-stakeholders [97] } \\
\text { dialogues, consensus building, } \\
\text { decision-making, and } \\
\text { implementation [98] }\end{array}$ \\
\hline Knowledge Transfer & Meetings & Tourism Type \\
\hline $\begin{array}{l}\text { - } \quad \text { Knowledge management [97] } \\
\text { - } \quad \text { Field trips to other communities } \\
\text { with similar interests in tourism } \\
\text { development [48] } \\
\text { - } \quad \text { Subjects and courses in tourism } \\
\text { planning [48] } \\
\text { - } \quad \text { Information on the entrepreneurial } \\
\text { opportunities in tourism [48] } \\
\text { Descriptions of positive and } \\
\text { negative impacts of tourism, } \\
\text { illustrated with cases studies and } \\
\text { examples [48] }\end{array}$ & $\begin{array}{ll}\text { - } & \text { Public meetings [48] } \\
\text { - } & \text { Workshops and working groups [81] } \\
\text { - } & \text { Focus groups [48] } \\
\text { - } & \text { Seminars [48] } \\
\text { - } & \text { Participation in councils and } \\
\text { - } & \text { Fommittees [81] } \\
\text { - } & \text { Organization in initiatives and } \\
\text { - } & \text { Future labs and open space [81] }\end{array}$ & $\begin{array}{l}\text { - Feasibility assessments for } \\
\text { different types of tourism } \\
\text { development [48] } \\
\text { - } \quad \begin{array}{l}\text { Rural tourism as a tool for rural } \\
\text { development, promoting a certain }\end{array} \\
\text { kind of tourism [100] } \\
\text { - } \quad \text { Community-based tourism [12] } \\
\text { - } \\
\text { Eco-based tourism }\end{array}$ \\
\hline
\end{tabular}

To summarize, the theoretical background has explored the fundamentals of DG, which specifically address stakeholder participation, with a special focus on local residents. Especially in the debate on overtourism, the role of DG in relation to residents needs reconsideration. This can be done by implementing different tools. A special meeting format that addresses the criteria of cross-stakeholder participation and innovation discussion is the Living Lab (LL). A LL can be described as a user-centric or also user-driven innovation environment, where managers, creators, and all kinds of users interact in developing innovations with a social and economic impact [27]. So far it has been applied with a resident focus in different disciplines [101-103], but it still lacks widely accepted definitions and frameworks [104] or knowledge about cooperative mechanisms for innovation [105,106]. In tourism, the LL has only been introduced a few times $[25,107,108]$. As there is a research gap in adopting the LL for tourism purposes, it is necessary to identify the characteristics of the LL and to contextualize its basic causal mechanisms with established coordination-logics applied in DG. Therefore, the following systematic literature review (SLR) will tackle the following research questions: (1) What are the characteristics and mechanisms of Living Labs (LLs)? and (2) How can the LL be utilized to promote the participation of residents in the context of destination governance (DG)?

\section{Methodology: Systematic Literature Review on Living Labs}

In order to gain insights into the subject area of LLs, a systematic literature review (SLR) was performed. An SLR aims to identify research articles in a systematic and reproducible way by implementing several search criteria [109-114]. An SLR therefore delivers a framework for classification and analysis, identifies research gaps, and can be matched with criteria of DG to build areas for future research [115-117]. Compared to a traditional narrative review, an SLR is less rigid [118,119] and can be perceived as a "stand-alone piece of research that clearly delineates a field and provides answers to quite specific questions." [116]. Moreover, an SLR is a valid and specific methodology that can follow a specific research question and allow clear conclusions and practical reports [114,119]. Literature'reviews, in addition to systematic, can also be semi-systematic or integrative [119].

A discipline that frequently applies an SLR to enhance the knowledge base and to provide information for policy makers and practitioners is medical science [117]. SLR papers are also published 
in the wider social sciences [117], business (e.g., [120]), organization theory [121], and hospitality and tourism. Out of the hundreds of SLRs in tourism, examples include reviews on innovation [122], data management [123], the resource efficiency of tourist accommodation [116], sustainable tourism in a developing country [112], networked collaboration in tourist destinations [124], networks in tourism management studies [115], gendered travel risk [118], and the effects of online reviews on tourism consumers and providers [125]. It is noticeable that the used research questions range from confirmatory to exploratory. This is also why both qualitative and quantitative approaches are applied in SLRs [124,126], or even combined, as a qualitative SLR helps in assessing the quality of the research findings [119]. This is also supported by the use of qualitative content analysis [125]. Nevertheless, statistical methods are also meaningful for an SLR, namely, a meta-analysis or bibliometric analysis to uncover the structures of a research field $[117,119,124]$.

This paper follows the concept to provide a broad research question, which is analyzed by basic quantitative analysis of the research field, but also by a detailed qualitative exploration of characteristics and mechanisms of the LL. The steps for conducting an SLR can vary according to their standardization [126], but follow the basic pattern in Figure 3. However, not all guidelines on SLRs include the last phase, "Reporting and Dissemination," which is especially relevant to analyze and synthesize evidence for future research and practice $[109,113,117,126]$.

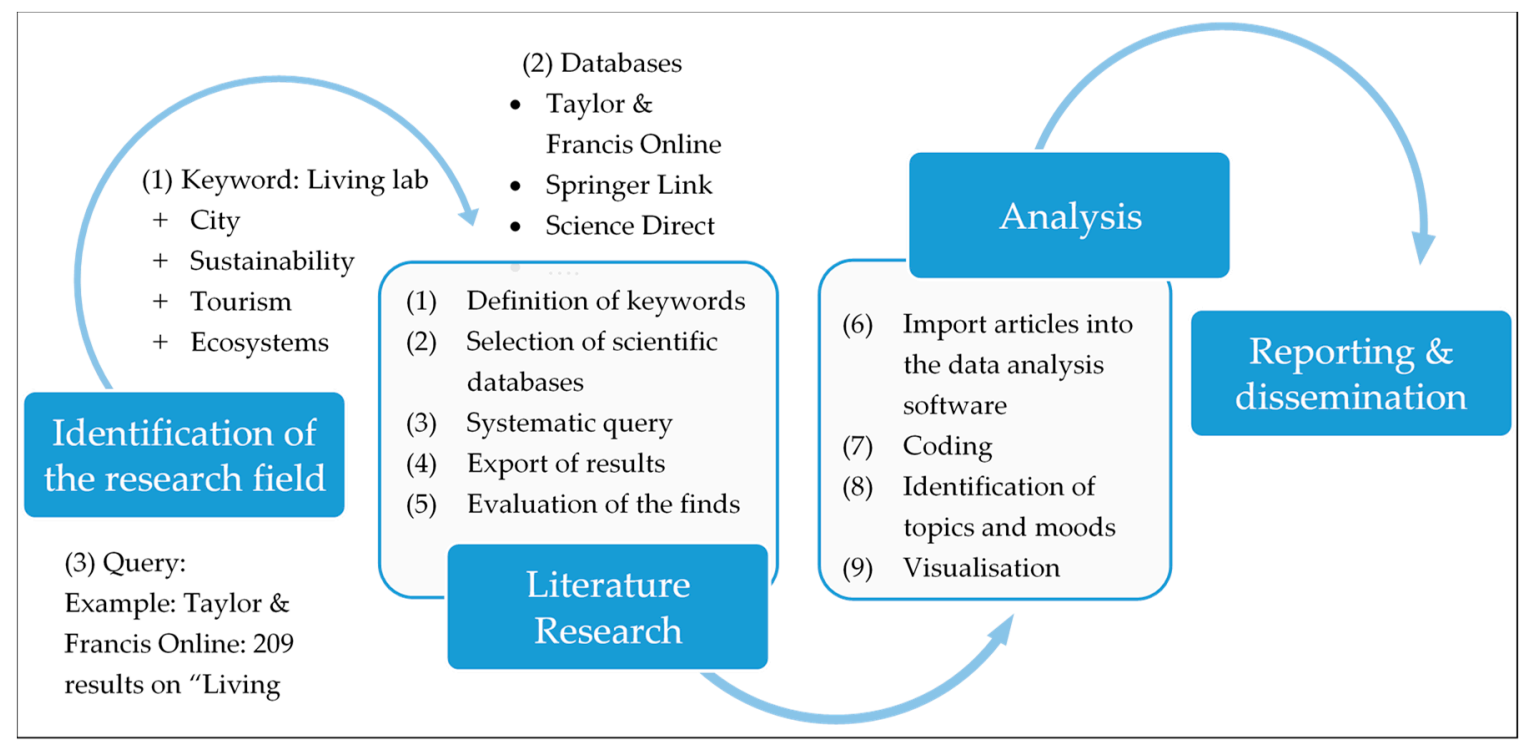

Figure 3. Procedure of the Systematic Literature Analysis. Source: Own elaboration based on Galvan and Galvan (2017) [127], Bortz and Döring (2009) [128], O'Neill and Booth (2017) [129], O'Neill et al. (2018) [130], and Tranfield et al. (2003) [117].

In order to cover the subject area as broadly as possible and to take the relevant literature into account, the following six characteristics for the structure of the literature were observed: (1) focus, (2) goal, (3) perspective, (4) coverage, (5) organization, and (6) audience [110]. Thus, in a first step, keywords and keyword combination that are crucial to the LL were defined: "living labs," "living labs city," "living labs sustainability," "living labs tourism" and "living labs ecosystem." In a second step of the systematic literature analysis, a search for suitable publications in online databases was undertaken. The following databases were used: Taylor \& Francis Online, Springer Link, ausmt.org, Science Direct, WISO, media TUM, Web of Science, Technology Innovation Management Review, mdpi.com, AOSIS, and Emerald insight. Including numerous databases was necessary because the search queries delivered only a few results. For example, a search via Web of Science using the term "living labs" resulted in 209 articles. Those articles were further adjusted by evaluating the articles according to their topic and relevance for the literature review. At the final stage, a search query on Google Scholar was conducted to ensure that major contributions were included. This study focused 
on journal articles; hence, other publications (e.g., conference papers and books) were not taken into account. In addition, the search was limited to English-language articles from the last 10 years (Table 2). To provide quantitative data, a total of 40 articles were identified using this procedure.

Table 2. Publishing Dates.

\begin{tabular}{ccccccccccc}
\hline Year & 2009 & 2011 & $\mathbf{2 0 1 2}$ & $\mathbf{2 0 1 3}$ & $\mathbf{2 0 1 4}$ & $\mathbf{2 0 1 5}$ & $\mathbf{2 0 1 6}$ & $\mathbf{2 0 1 7}$ & $\mathbf{2 0 1 8}$ & $\mathbf{2 0 1 9}$ \\
\hline Number of Articles & 2 & 1 & 6 & 6 & 2 & 3 & 3 & 6 & 7 & 4 \\
\hline \multicolumn{8}{c}{ Source: Own elaboration. }
\end{tabular}

The 40 papers selected represent a variety of journals and issues. Due to the marginal nature of the Living Lab approach in current research, the literature review included a wide range of 27 journals. The Technology Innovation Management Review (TIM Review) contributed 12 articles to this literature review, especially from the three special issues on LLs that were published over the last 10 years. Other journals such as Research Technology Management contributed to a cluster of articles on technology, innovation, and management. Further articles relate more to engineering or to regional studies (Table 3). Eighty-five authors and 40 articles were used; Seppo Leminen and Anna Ståhlbröst contributed to four articles.

Table 3. Academic Fields of Selected Journals.

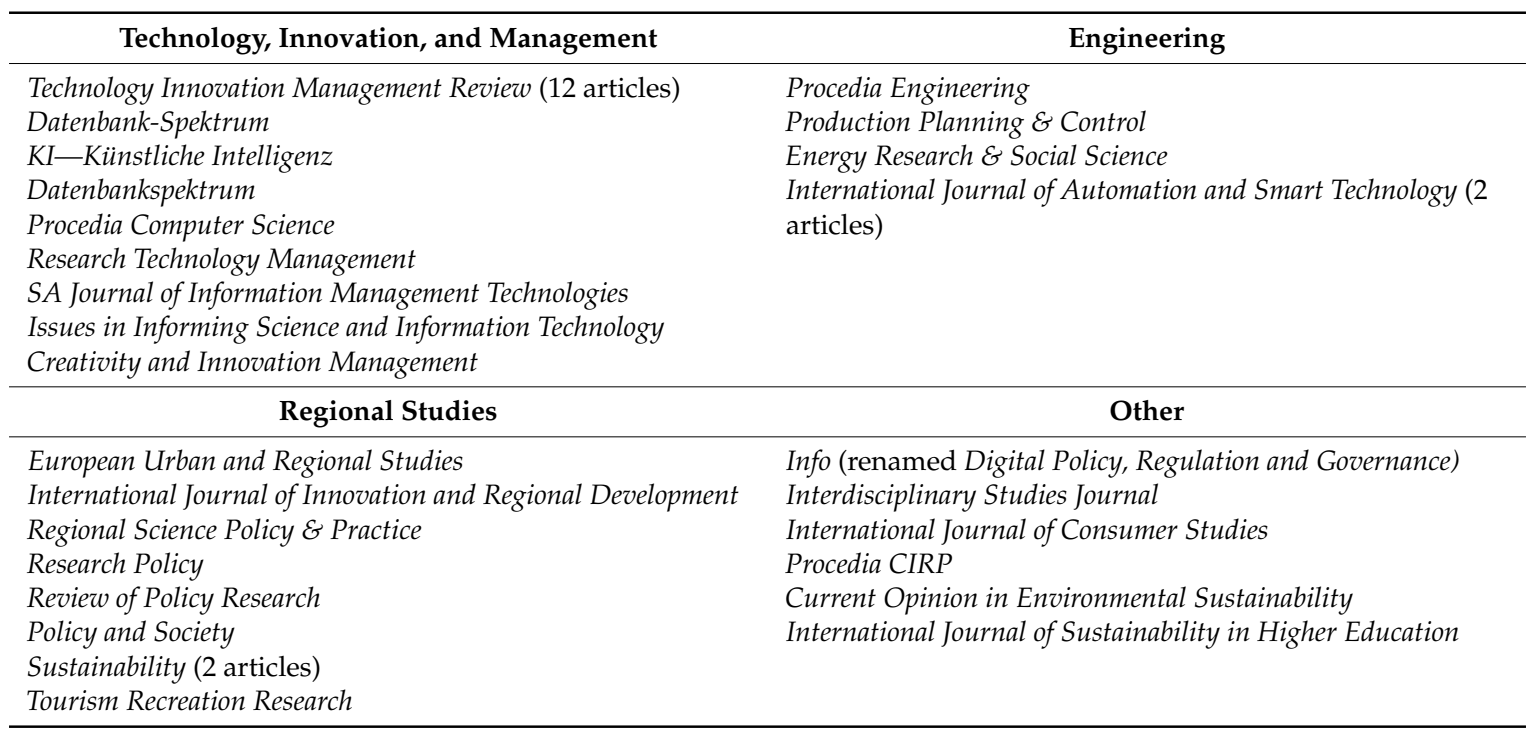

Source: Own elaboration.

For the data analysis itself, the qualitative data analysis software NVivo was used to manage and visualize the data using descriptive research [131,132]. NVivo "enables creation of a snapshot of each theme ... to highlight the gaps in the literature ... (and) to conduct an effective analysis of the literature" [130] (p.23). Following the example of O'Neill and Booth (2017) [129] and O'Neill et al. (2018) [130], the project was initially prepared by importing the articles obtained from the database analyses. Within the framework of the analysis, an identification of topics and methods was carried out after coding and before visualizing the results. For example, a word cloud or cluster analysis was created within a more quantitative analysis, whereas the different characteristics of the LL were explored in a qualitative analysis. In a final step, the results of the SLR were linked to the characteristics of DG in order to identify commonalities and dichotomies.

\section{Results: Framing Living Labs}

The research results evolved through the above-described SLR. Based on the 40 research papers on the LL, this section starts with an overview of these articles by including word count, cluster analysis, 
exemplary papers, and the identification of applied theories, concepts, and methods (Section 4.1), before exploring concrete LL dimensions, such as definitions, spaces and fields of application, target groups, and tools (Section 4.2). The data allow for a decent view on the role of LL in community or residents' participation (Section 4.3).

\subsection{Content Overview}

An overview of the collected literature in terms of content can be provided by word counting. By the support of text mining with NVivo, it is possible to count, list, and illustrate the number of words used in all articles (Figure 4). All words are compromised by their word stem, meaning that, for example, the term "innovators" represents a pool of similar words, such as innovation(s) or innovative. The extraction of the 22 most often used words on the right shows first that the papers used confirm their central issue "living lab" and second, the word count links the LL to issues of innovation, user involvement, research, cities, products and services, and community. A similar picture occurs by having a look at the number of codes-through manual coding and through automatic coding. The most often coded keywords (including subcodes) are city, collaborative, community, data, development, environment, and innovation. Further support can be found by the titles of the papers. All titles involve the term living lab (40), followed by innovation (16), city (11), design (six), urban (six), smart (five), test (five), and collaboration (four).

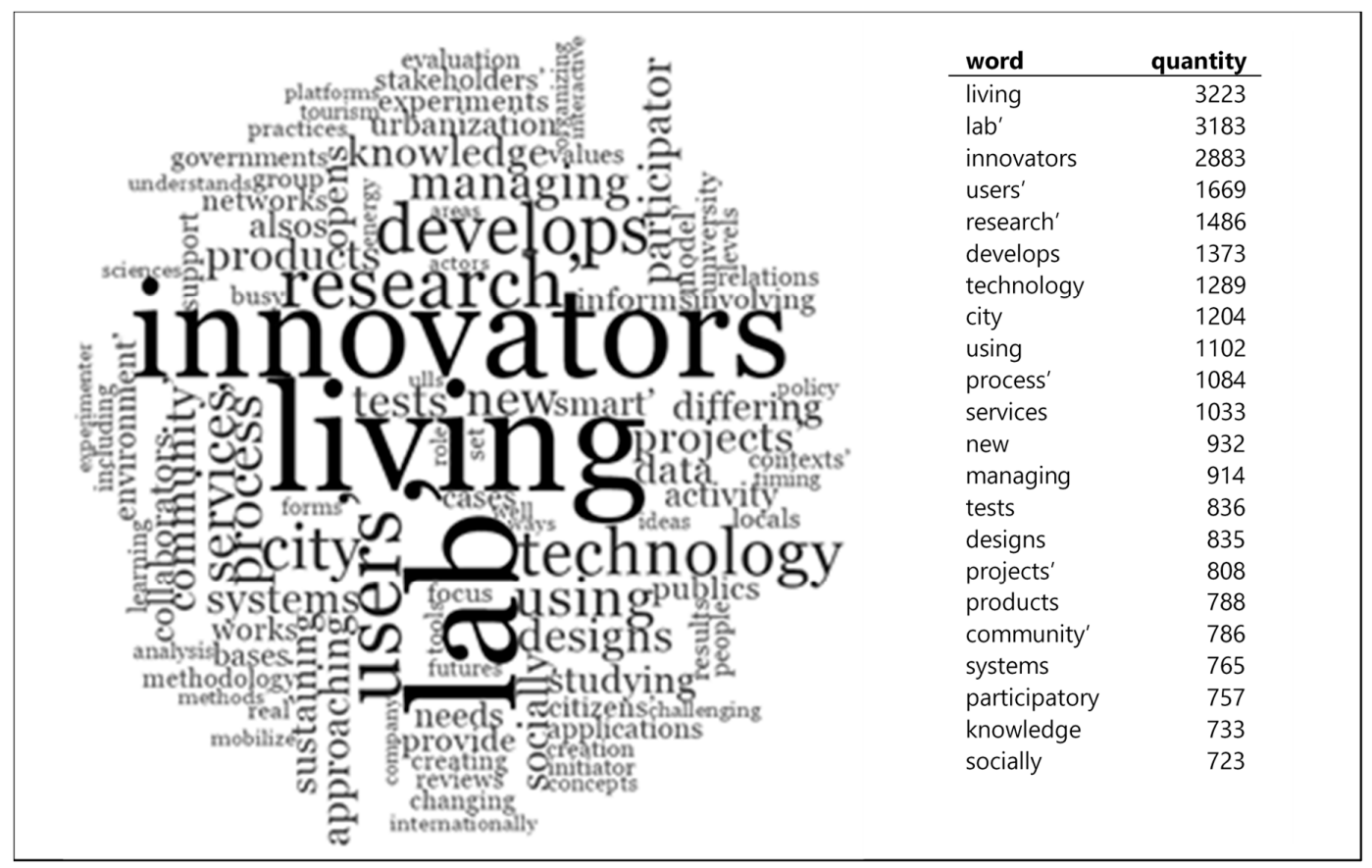

Figure 4. Major Keywords. Source: Own elaboration.

Through computer-assisted calculation in NVivo, clustering the papers based on the distance of used words (Pearson correlation index) is feasible. Figure 5 shows the five clusters, which have been manually named. The affiliation of a paper to a certain cluster is again based on the calculated word distance/proximity.

The Urban Transition cluster describes the increased confrontation with the implementation of sustainability issues in cities and the need to succeed a sustainably transition [133]. The LL could assist this transition by providing a space for testing and experimenting [134], for example on mobility and governmental services. A strength of the LL is that residents can already be involved in an early planning phase [103]. The publications on Life \& Work focus also on governance issues [135], but proceed towards local entrepreneurship [107], social innovation [136], or the design of the future workplace [137]. The Smart City cluster has high relevance in the LL research. The idea of the smart city 
has evolved over the past 10 years, but has changed its perspective towards a more community-driven, creative, and collaborative concept. Promoted by technological opportunities, smart cities shall provide an ecosystem for open innovation, smart and digital applications, and data connectivity [138]. The selected papers mostly consider the LL as a tool to test smart city applications and to involve the citizens in an appropriate manner during this testing and planning phase. In addition, three papers are summarized in the Infrastructure and Data cluster. Those contributions focus on the role of ICT infrastructure in smart cities [139] or privacy issues in a smart city [140]. The Characteristics and Design cluster of LL collects three subclusters, although these articles share a focus on user-driven innovation. Some of them discuss the collaboration and cooperation in a city context [141], others in a university context [106]. Closely related are concepts such as co-creation [142] and citizen empowerment [25,138]. Within this cluster, there are publications that show an especially high correlation (Pearson correlation $>0.74)$, which are connected by thick lines.

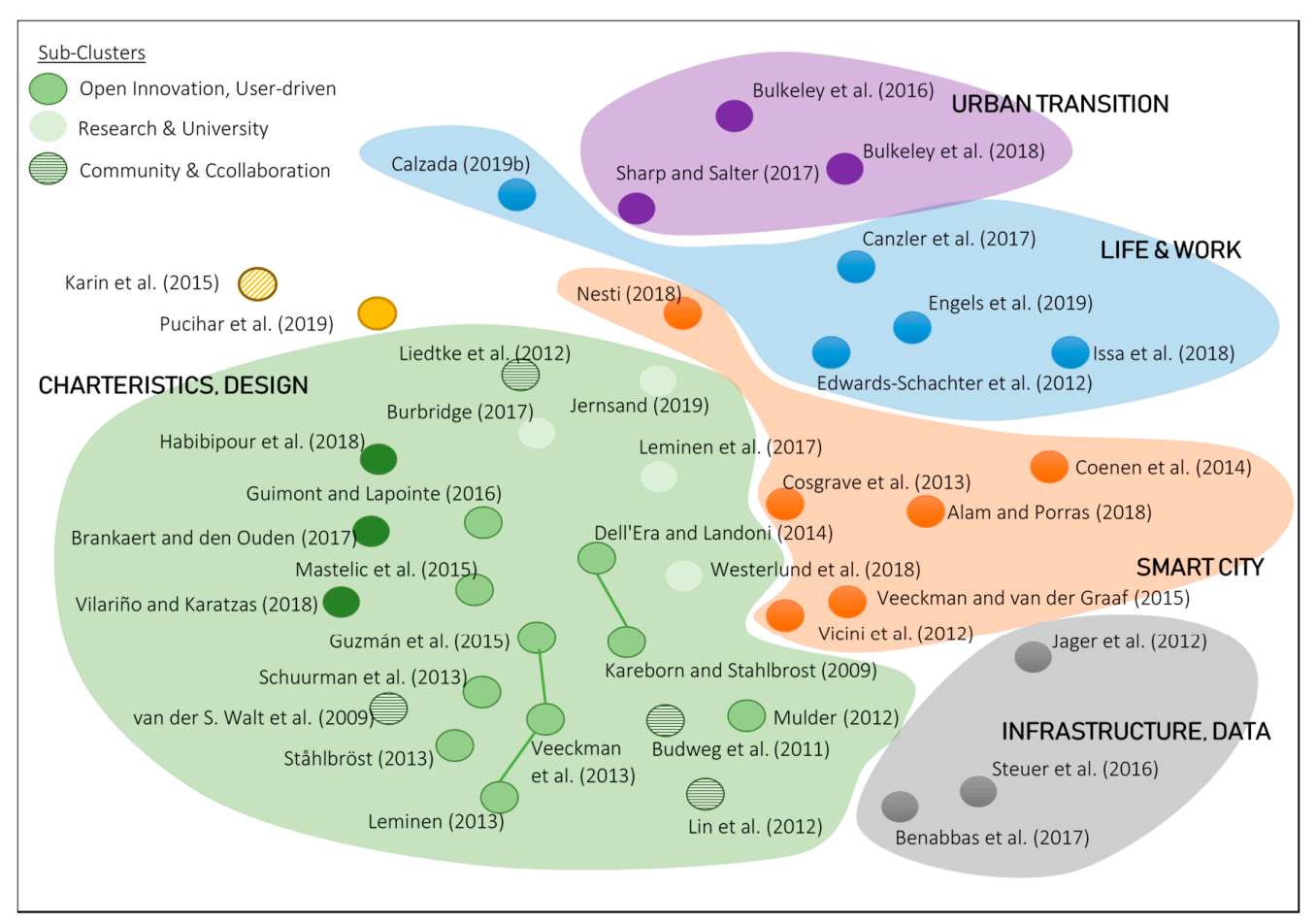

Figure 5. Clusters of the Literature on Living Labs (LLs). Source: Own elaboration.

Out of the last cluster, two central papers (number or references higher than 1500) are also suitable for the discussion of residents' participation:

- The article by Budweg et al. (2011) deals with the Living Lab approach in the context of the multi-year integrated project ECOSPACE. Living Lab is understood "as an environment of user-driven open innovation resulting in the development and implementation of concrete innovation projects through a process of experimentation and evaluation" [143] (p. 595). Since communication and collaboration platforms are today mostly unstructured or heterogeneous, this article discusses the active involvement of users through evaluations in an adapted Living Lab framework. A new and innovative model of collaboration for experts, who are here called eProfessionals and work together over the Internet, is being developed especially for their needs. Finally, technology development within the Living Lab activities still poses some challenges, and facing them can be described as a complex enterprise, as careful coordination of the different stakeholders throughout the innovation cycle is required.

- Leminen et al. (2017) deals with the next generation of Living Lab networks in urban contexts, where third-generation living labs are defined as "platforms with shared resources, [and these platforms] 
organize their stakeholders into a collaboration network(s), [which] relies on representative governance, participation, open standards, and diverse activities and methods to gather, create, communicate, and deliver new knowledge, validated solutions, professional development, and social impact(s) in real-life contexts" [144] (p. 22). The studies also show that cities in particular can benefit from innovation networks (e.g., the use of several platforms). Cities need to adapt their existing thinking and become active as coordinators rather than executors. In addition, citizens must be seen as active participants in innovation and not as subjects. Finally, the paper ends with a number of recommendations-for example, that the involvement of stakeholders should be strengthened over the long term, as this will result in benefits for all sides.

This overview closes with a summary of concepts, methods, targets, and scales applied in the selected papers. Table 4 shows the main characteristics of the research stream on LLs. The analyzed papers show some similarities. For example, they mostly discuss the question of how to design an LL such that it can be operated successfully. Furthermore, the research stresses user or community participation and supports the thesis that the LL is an important tool to involve community in general. The discussion of community participation is mostly linked to issues of city planning. In terms of the underlying research, with a focus on residents' participation, authors tend to highlight concepts, such as urban governance, community development, transition research, participatory design, applications on a destination scale, and the research targets of community interaction.

Table 4. Concepts, Methods, Scales, and Research Targets.

\begin{tabular}{|c|c|}
\hline Theories and Concepts & Research Target \\
\hline $\begin{array}{ll}\text { - } & \text { Urban governance [133] } \\
\text { - } & \text { User behavior [145] } \\
\text { - } & \text { Innovation and open innovation model }[25,137] \\
\text { - } & \text { Social innovation [136] } \\
\text { - } & \text { Business Model Canvas [146] } \\
\text { - } & \text { Communedge spillovers and management }[26,147] \\
\text { - } & \text { Change and transition research }[103,143,146,149] \\
\text { - } & \text { Experienced value of services }[150] \\
\text { - } & \text { Systems thinking }[104,141] \\
\text { - } & \text { Co-creation }[151] \\
& \text { Participatory schemes }[27,103,107]\end{array}$ & 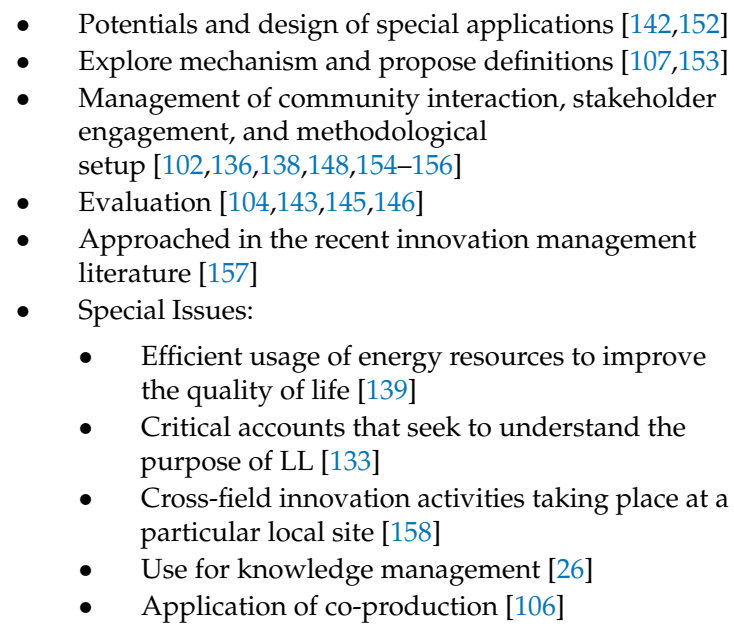 \\
\hline Methods & Scale \\
\hline $\begin{array}{ll}\text { - } & \text { Case study }[101,135-137,142,147,150] \\
\text { - } & \text { Comparative analysis }[133] \\
\text { - } & \text { Titerature review }[107,153,157] \\
\text { - } & \text { Grounded theory }[26] \\
\text { - } & \text { Ethnographic description and analysis }[106,158] \\
\text { - } & \text { Interviews and other qualitative information }[106,145]\end{array}$ & $\begin{array}{ll}\text { - } & \text { Single Living Labs }[153,156] \\
\text { - } & \text { City networks [139,148] } \\
\text { - } & \text { ULL networks, e.g., ENOLL }[107,159] \\
\text { - } & \text { - Mecial settings: } \\
\text { - } & \text { Work environments }[137,143] \\
\text { - Innovation campus }[106,158] \\
\text { - } \text { Urban smart energy campus and a rural } \\
\text { - } \text { - Destination }[25] \\
\text { - Cocial media [26] }\end{array}$ \\
\hline
\end{tabular}




\subsection{Characteristics of Living Labs}

The subsequent chapter introduces findings based on a more qualitative analysis: definitions of the LL, as well as certain characteristics, namely, the field and scales of application, stakeholders, targets, principles, and tools.

\subsubsection{Components of the Definitions}

The numerous definitions provided by the analyzed papers on the LL have several factors in common. Most authors include cooperation when defining the LL: "effective ways of managing synergies" [101], "support collaboration and communication among stakeholders" [101], "cooperation systems" [143], "inter-institutional collaboration," [27] or "platforms with shared resources, which organize their stakeholders into a collaboration network(s)" [144]. The second most important component is experiments and testing, which stresses the importance of LL for real-world testing and the evaluation of innovations in close relation to the users $[104,145,154]$. Therefore, the LL can serve as "an environment of an experiment" [144] to test, e.g., "newly invented information technology" [143] or to include "design, applications development, prototyping, ( . . ) , training activities, etc." [101]. Besides testing, the LL is considered to be a driver for innovation and joint value creation [151]. This is especially true for open innovation $[101,137,156]$, as the LL provides "expertise in many diverse areas" [150], which goes beyond the usual communities [143]. That is why the LL is also recognized in public and stakeholder management for active involvement of different communities [101]. Moreover, the LL is defined by its user-centered product design, which is also based on a participative design approach by the support of technological solutions [101]. Additional factors of the LL definitions are, for example, the living lab infrastructure [147], the management of knowledge flows [101] or the living lab as a specific research approach [150]. To summarize those components, a definition can be derived:

Living Labs are cooperative environments that follow a user-driven and cross-stakeholder approach in order to provide a shared space for experiments and tests of innovative products and services in a real-life environment. Living Labs offer digital infrastructure and can be perceived as a research approach, which includes design elements to support collaborative innovation processes. Living Labs can operate on different scales and purposes, e.g., for public discussions on sustainable transition or companies' product testing.

\subsubsection{Fields of Application}

The LL offers a diverse set of possible applications, which will be explored later. On a practical level, Burbridge (2017) [149] provides a collection of applications, ranging from health issues, to economic topics for small and medium sized enterprises, business models, and innovations, and to public challenges in energy and environmental transformation, sustainable technologies, eco-cities and smart cities, and community innovation [149]. On a more abstract level, the analyzed papers focused on the following: (1) cities [133,139,143,148], (2) the living lab itself [102,153,158], (3) tourism destinations [25,107], (4) companies [137], and (5) LL networks, such as EnoLL [154]. Support was provided by Westerlund et al. (2018) [157], who additionally focused on (6) ecosystems [157]. In a different categorization, Schuurman et al. (2013) [147] proposed the division into micro, meso, and macro scales $[25,147]$. We point out here that only two contributions considered tourism destinations as a subject of analysis.

\subsubsection{Stakeholders}

The strength of the living lab approach is to include a "wide range of stakeholders at the micro and meso level" [25]. This allows one to gather information and user requirements from different fields [148]. LLs are not limited to either a public or a private purpose; in contrast, they involve users from both public and private parties [102,149]. To categorize the different stakeholders, Calzada (2019) defined these five stakeholder groups: the public sector, the private sector, civic society, academia, 
and entrepreneurs [107]. Based on the underlying literature analysis, five slightly different groups can be determined:

1. public authorities, including the municipal authority $[134,139]$, which also provides access to the community network [143], lab investors, and universities [139]. This can be also supplemented by regional authorities [104,148];

2. communities, including NGOs [134], urban civil society [134], community organizations [134,143], living lab facilitators [143], and residents as the key stakeholders in the case of smart cities [148];

3. developers and researchers in order to technically support the LL and to design and monitor processes on an academic level $[25,101,143]$;

4. entrepreneurs, including start-ups, SMEs [104,145], and, depending on the case, employees [153];

5. tourists $[105,139]$ as a specific user group, which includes leisure activities for residents [134].

\subsubsection{Motives}

The motives of the stakeholders to take part in an LL are seldom defined. LLs can help public authorities and companies to (1) get in touch with the community or a specific target group [139,142] in order to meet their needs with new products or services [141], (2) gather information and (3) detect impulses for innovations; LLs can help individual participants to (4) represent a certain position within the discussions at the L; for processes at a regional level, LLs can help one to (5) balance the interests between local demands and further target groups [143]. For the case of company-driven living labs, Leminen et al. (2017) [144] state that mainly short-term objectives are relevant, which could probably be in opposition to LLs that target central development issues in a city context.

\subsubsection{Targets}

Certain subtargets of LLs can be defined under the notion of the main objective to "develop, experiment and exploit innovation in real life scenarios" [153]:

1. innovation support, including idea generation [143], knowledge transfer [26,141], facilitating user tests [156], and performance improvement [141];

2. bringing stakeholders from different field and their related interests together $[138,140,151,158]$;

3. consensus building to the fulfilment of joint objectives $[133,143]$, which also recognizes the societal complexity [102] and practical implications [160];

4. community involvement and participation in the sense of a bottom-up approach $[26,105,106,138,160]$;

5. well-being and sustainability, including social innovation [136], the creation of prosperous communities [141], the transition to more sustainable lifestyles [103], or sustainability thinking [141,144].

\subsubsection{Principles}

The LL follows several principles to achieve the abovementioned targets in a decent way. For example, (1) the innovation process should be as open as possible, (2) users should play a key role, (3) community interactions should be meaningful and sustainable and (4) should be in a human-centric setting that provides space for empathy but also (5) for observation and analysis. Moreover, a central element of LLs is (6) to provide an adequate technological infrastructure that assists all lab processes $[25,105,156]$.

\subsubsection{Tools}

Based on the principles mentioned, a variety of tools support the processes in an LL. In practical applications, the selection of tools should suit the purpose of the LL or a specific problem statement [26]. The presented tools (Table 5) include digital tools, as well as personal interaction, measuring tools, and design thinking. 
Table 5. Applied tools in LLs.

\begin{tabular}{|c|c|c|}
\hline Web Application & Feedback, Evaluation, and Measuring & Data, Knowledge, and Analysis \\
\hline $\begin{array}{ll}\text { - } & \text { Web } 2.0 \text { tools, wikis, and blogs }[143,148] \\
\text { - } & \text { Social media }[26,146] \\
\text { - } & \text { Semantic web [26] } \\
\text { - } & \text { Lab portaboration platforms and group blogging }[143] \\
& \text { Software tools and services for remote } \\
& \text { council meetings [101] }\end{array}$ & $\begin{array}{ll}\text { - } & \text { Indices for measuring progress [148] } \\
\text { - } & \text { Experimenting and evaluating } \\
\text { innovative tools [143] } \\
\text { - } & \text { Feedback [143] } \\
\text { - } & \text { Question and answer } \\
& \text { extrapolation [26] } \\
\text { - } & \text { Diagnostic tools [143] } \\
\text { Evaluating new collaboration } \\
\quad & \text { concepts [143] } \\
\text { - } & \text { Usability inspection [101] } \\
\text { - } & \text { Story-based evaluation [103] } \\
\end{array}$ & $\begin{array}{ll}\text { - } & \text { Standard data and text mining } \\
\text { tools [26] } \\
\text { - } & \text { Content analysis technique [144] } \\
\text { - } & \text { Learning and reporting [143] } \\
\text { - } & \text { Knowledge management } \\
& \text { tools [101] } \\
\text { - } & \text { Spatial analysis [101] }\end{array}$ \\
\hline Design & Multimedia & Personal Interaction \\
\hline $\begin{array}{ll}\text { - } & \text { Emotion Generative Design } \\
& \text { Research [153] } \\
\text { - } & \text { Participatory design [101] } \\
\text { - } & \text { Performance thinking }[141] \\
\text { - } & \text { User-Centered Design }[142,153] \\
& \text { Scenario building and ethnographic } \\
& \text { toob,138] }\end{array}$ & $\begin{array}{l}\text { - } \quad \text { Recorders, video cameras and physical } \\
\text { artifacts [153] } \\
\text { - } \quad \text { Visual tools [106] } \\
\text { - } \quad \text { ICT tools [141] } \\
\text { - Collage, narration [153] }\end{array}$ & $\begin{array}{ll}\text { - } & \text { Expert Mindset [153] } \\
\text { - } & \text { Training to users [143] } \\
\text { - } & \text { Communicate tools [143,154] } \\
\text { - } & \text { Focus groups and end users [101] } \\
\text { - } & \text { Consshops, discussions }[101,106] \\
& \text { Consution [134] }\end{array}$ \\
\hline
\end{tabular}

Source: Own elaboration.

To summarize, LLs provide a wide set of tools that follow principles that especially suit an open dialogue across different stakeholder groups in order to follow joint obstacles and to allow participation, involvement, and innovation. Figure 6 shows the results of the explored characteristics of the LL, which will later on be matched with DG criteria. LLs come in very different forms, and not all characteristics need to be fulfilled at once, but they still provide orientation.

\begin{tabular}{|c|c|c|c|c|c|}
\hline \multicolumn{6}{|c|}{ LIVING LABS } \\
\hline (A) Spaces & $\begin{array}{l}\text { 1. City } \\
\text { 2. Destination }\end{array}$ & $\begin{array}{l}\text { 3. Singl } \\
\text { 4. Com }\end{array}$ & $\begin{array}{l}\text { iving labs } \\
\text { ny }\end{array}$ & $\begin{array}{l}\text { 5. LL networks } \\
6 . \text { Ecosystems }\end{array}$ & \\
\hline (B) Stakeholders & $\begin{array}{l}\text { 1. Public authorities } \\
\text { 2. Community }\end{array}$ & \multicolumn{4}{|c|}{$\begin{array}{l}\text { 3. Developers and researchers } \\
\text { 4. Entrepreneurs }\end{array}$} \\
\hline (C) Motives & $\begin{array}{l}\text { 1. Get in touch } \\
\text { 2. Gather information }\end{array}$ & \multicolumn{4}{|c|}{$\begin{array}{l}\text { 3. Detect impulses for innovation } 5 \text {. Balancing interests } \\
\text { 4. Represent opinions }\end{array}$} \\
\hline (D) Targets & \multicolumn{2}{|c|}{$\begin{array}{l}\text { 1. Innovation support } \\
\text { 2. Bring together stakeholders }\end{array}$} & \multicolumn{2}{|c|}{$\begin{array}{l}\text { 3. Consensus building } \\
\text { 4. Community involvement }\end{array}$} & $\begin{array}{l}\text { 5. Well-being \& } \\
\text { sustainability }\end{array}$ \\
\hline (E) Principles & \multicolumn{3}{|c|}{$\begin{array}{l}\text { 1. Openness } \\
\text { 2. Users in key roles } \\
\text { 3. Meaningful \& sustainable interaction }\end{array}$} & \multicolumn{2}{|c|}{$\begin{array}{l}\text { 4. Human-centric setting } \\
\text { 5. Space for observation } \\
\text { 6. Technological infrastructure }\end{array}$} \\
\hline (F) Tools & \multicolumn{3}{|c|}{$\begin{array}{l}\text { 1. Web applications } \\
\text { 2. Feedback, evaluation, and measuring } \\
\text { 3. Data, knowledge, and analysis }\end{array}$} & \multicolumn{2}{|c|}{$\begin{array}{l}\text { 4. Design } \\
\text { 5. Multimedia } \\
\text { 6. Personal interaction }\end{array}$} \\
\hline
\end{tabular}

Figure 6. Characteristics of LLs. Source: Own elaboration.

\subsection{Living Labs in Residents' Participation}

By following targets such as consensus building and stakeholder involvement, this section focuses on the participation of residents in LL processes. Therefore, representative and different quotations have been selected to address the opportunities of the LL in residents' participation. The analysis is 
based on the matching of different keywords within a coded passage, which also involves subkeywords: stakeholder and community, as well as involvement, participation, and innovation. The terms involvement and participation are often used as synonyms. Table 6 presents the number of text passages that involve both of the crossing keywords. One example that discusses residents' participation in a tourism context will be cited here. Pucihar et al. (2019) stress tourists as a source of innovation and a target group-oriented approach: Through living labs, "tourist service providers will obtain insight into what tourists actually want and will have an opportunity to improve and develop new services targeted to different customer segments" [152]. By expanding this user-centric approach, the ideal LL is probably a user-driven LL, which is fully based on self-governance.

Table 6. Quotations on residents' participation. Source: Own elaboration.

\begin{tabular}{|c|c|c|}
\hline & Stakeholder & Community \\
\hline \multirow[b]{2}{*}{ Involvement } & 9 & 11 \\
\hline & $\begin{array}{l}\text { - }[\text { LL as] an organized set of methods and } \\
\text { stakeholders, which focus on user involvement and } \\
\text { user-centric research methodology [ ... ] in real-life } \\
\text { contexts [153] } \\
\text { - An ecosystem of stakeholders who can interact to } \\
\text { develop and asses products, services, [ ... ] [25] } \\
\text { - [LLs as] innovation projects, that are characterized } \\
\text { by active user involvement, co-creation, } \\
\text { multi-method and multi-stakeholder, as the meso } \\
\text { level [25] }\end{array}$ & $\begin{array}{l}\text { - The Living Lab [... ] focused on community } \\
\text { building and active user involvement in the } \\
\text { process of developing, introducing, and } \\
\text { evaluating new collaboration concepts and } \\
\text { tools [143] }\end{array}$ \\
\hline \multirow[b]{2}{*}{ Participation } & 11 & 8 \\
\hline & $\begin{array}{l}\text { - tools to support interaction among stakeholders, } \\
\text { which typically include user communities [101] } \\
\text { Institutes, and all the involved stakeholders have } \\
\text { decision-making power [105] } \\
\text { - A key feature is that users become fully fledged } \\
\text { stakeholders in the co-creation process and are } \\
\text { involved from the very beginning } \\
\text { living labs could create increased collaboration } \\
\text { opportunities through a common platform where } \\
\text { stakeholders would share, discuss, assess, and } \\
\text { design various solutions [25] }\end{array}$ & $\begin{array}{l}\text { - Locally rooted organic place-making and } \\
\text { emergent participatory planning processes are } \\
\text { required to enhance community participation in } \\
\text { the decisions that shape people's surroundings. } \\
\text { [ ... T The experimental interventions that } \\
\text { empower local communities regarding the role } \\
\text { of tourists as visitors [105] } \\
\text { Community participation would outlast the } \\
\text { short time frame of the LL with the support of } \\
\text { active citizens working together for the } \\
\text { governance of sustainability transition in their } \\
\text { local community [103] }\end{array}$ \\
\hline \multirow[b]{2}{*}{ Innovation } & 81 & 54 \\
\hline & $\begin{array}{l}\text { - living labs should involve end users in constructing } \\
\text { meaningful innovation with and for them through } \\
\text { co-creation [102] } \\
\text { it is the focus on the creation of a new learning } \\
\text { arena that marks out this particular type of } \\
\text { governance innovation from other kinds of urban } \\
\text { experimentation [133] } \\
\text { local entrepreneurship requires socially innovative } \\
\text { approaches with complex tools to enhance strategic } \\
\text { and prospective capabilities and scale them up } \\
\text { among citizens (residents/locals or } \\
\text { visitors/tourists) [105] } \\
\text { an innovation platform that engages all } \\
\text { stakeholders, such as end users, researchers, and } \\
\text { industrialists [26] }\end{array}$ & $\begin{array}{l}\text { Participative processes and citizens' } \\
\text { empowerment are considered crucial aspects of } \\
\text { social innovation, involving collaborative } \\
\text { activities between the private, public, and third } \\
\text { sectors [136] } \\
\text { to give citizens and individuals the opportunity } \\
\text { to engage in these innovation processes [156] } \\
\text { to create opportunities for a dynamic region } \\
\text { where boundary-crossing cooperation becomes } \\
\text { usual in the change processes on all levels from } \\
\text { product development to community } \\
\text { building [156] }\end{array}$ \\
\hline
\end{tabular}

To summarize, an SLR on the LL spawned 40 articles from a great variety of different journals and issues. The discourse on LL is a rather specialized research stream that is closely connected to the issues of collaboration, innovation, and smart city development. The main strength of the LL lies in its user-driven and cross-stakeholder approach, which is also suitable for residents' participation. The stated principles and applied tools support this thesis by defining the resident as one of the major stakeholders and to include them in the relevant processes. 


\section{Discussion: Living Labs for Residents' Participation in Destination Governance}

This paper has so far presented selected issues regarding residents' participation in DG and has provided an SLR on LL. This section will compare the characteristics and mechanisms of the LL with the requirements of DG in order to further promote residents' participation (Figure 7). This theoretical matching of LL and DG is the final step of the SLR (see Figure 3 and [117]). Further research is derived at every dimension within Section 6.

\begin{tabular}{|c|c|c|c|}
\hline & LIVING LABS & \multicolumn{2}{|c|}{ DESTINATION GOVERNANCE } \\
\hline (A) Spaces & City, Destination, ... & $\begin{array}{c}\text { Commonalities between } \\
\text { destinationand city planning }\end{array}$ & $\begin{array}{l}\text { Living space, Destination, Economic } \\
\text { region, ... }\end{array}$ \\
\hline (B) Stakeholders & $\begin{array}{l}\text { Public authorities, tourists, } \\
\text { community, entrepreneurs,... }\end{array}$ & $\begin{array}{c}\text { Flexible concepts for } \\
\text { including different groups } \\
\text { Initiator? Responsibility? }\end{array}$ & $\begin{array}{l}\text { Local community, tourism service } \\
\text { providers, related industries and } \\
\text { suppliers, tourists, education ... }\end{array}$ \\
\hline (C) Motives & $\begin{array}{l}\text { Get in touch, detect impulses for } \\
\text { innovation, balancing interests, } \\
\text { gather information, ... }\end{array}$ & $\begin{array}{l}\text { Joint development } \\
\text { Economic interests }\end{array}$ & $\begin{array}{l}\text { Leisure seeking, profit orientation, } \\
\text { public welfare, development }\end{array}$ \\
\hline (D) Targets & $\begin{array}{l}\text { Innovation support, consensus } \\
\text { building, well-being and } \\
\text { sustainability, bring together } \\
\text { stakeholders, community } \\
\text { involvement }\end{array}$ & \begin{tabular}{|c|} 
Impulses beyond \\
governance \\
Degree of community \\
participation, mixture of self- \\
organization \\
\end{tabular} & $\begin{array}{l}\text { Coordination and cooperation, } \\
\text { identity development } \\
\text { Innovation }\end{array}$ \\
\hline (E) Principles & $\begin{array}{l}\text { Openness, human-centric setting, } \\
\text { users in key roles, observation, } \\
\text { meaningful and sustainable } \\
\text { interaction, ICT, ... }\end{array}$ & $\begin{array}{c}\text { New role models and self- } \\
\text { organization } \\
\begin{array}{c}\text { Long-term engagement } \\
\text { Implement openness }\end{array}\end{array}$ & $\begin{array}{l}\text { Public participation, efficiency, } \\
\text { consensus orientation, equity, } \\
\text { accountability, strategic vision, } \\
\text { transparency, responsiveness, } \\
\text { effectiveness ... }\end{array}$ \\
\hline (F) Tools & $\begin{array}{l}\text { Web applications, feedback, } \\
\text { evaluation, and measuring, data, } \\
\text { knowledge, and analysis, design, } \\
\text { multimedia, personal interaction }\end{array}$ & $\begin{array}{c}\begin{array}{c}\text { Flexible set of tools for } \\
\text { personal and virtual } \\
\text { interaction }\end{array} \\
\text { Guidance and technology }\end{array}$ & $\begin{array}{l}\text { Guidelines and certifications, } \\
\text { communication, cooperation and } \\
\text { grouping, knowledgetransfer, } \\
\text { meetings, tourism type }\end{array}$ \\
\hline
\end{tabular}

Figure 7. Comparison of LLs and DG. Source: Own elaboration.

The LL approach addresses so far mostly the geographical scale of cities or the sphere of single companies. Seldom is the LL used at a destination scale [105]. However, as tourism development needs to recognize the residents' needs within a city perspective, this relation between LL and DG could work quite well through the necessity to include administrative and public spaces [25]. If the destination planning is open to the participation of residents, for example within the setting of an LL, the degree of participation [10] also becomes a matter of residents' attachment to the destination [90]. However, the LL and DG have in common that both involve several scales and could therefore be flexibly combined in planning.

The stakeholder groups need to be compared. The LL provides a relatively flexible body for practical implementations for entrepreneurs, communities, or public authorities, which are the stakeholders in a given destination. The more important question is of which group is responsible for operating the LL. The case studies of the LL research often embody a public authority that is implementing an LL for discussing certain urban issues. In a tourism context, the DMO could probably undertake this task as the lead actor. Arising from the debate on overtourism, the role of residents or even the specific subgroups of residents need to be carefully defined, as different interests also evolve through the legal frame of residency. Meaning that residents are as diverse in their motivations 
and modes of living as tourists are in their travel behavior. Therefore, special consideration in urban planning is necessary in issues such as the different typologies of residents or the role of ownership, privacy, or individualization.

The motives and targets of taking part in LL processes mostly address those of DG. For example, an LL balances interests within a broad set of stakeholders, while it is a central element of DG to bring together the relevant stakeholders and to begin cooperation as well as identity development. The LL is described within an SLR as a tool for consensus building, community involvement, and sustainability transition, but is also suitable for innovation or information-gathering. However, the degree of residents' participation in DG needs to be evaluated critically on a case-by-case basis. On an international scale, the local community is of course recognized as a stakeholder group, but seldom is it involved in clear decision-making processes. That is also why a potential mismatch between the two approaches could eventually evolve through the motives of tourism service providers that probably have business-related objectives, instead of through those of public authorities and residents that support well-being and sustainable development.

Furthermore, the principles on how to implement the concepts of LL and DG match quite well. The LL can be understood as a place for openness, interaction, technology, and observation, which allows all interested people to take part in discussions and innovation processes. DG follows a slightly more defensive approach by defining steering mechanisms and tools for coordination and cooperation. The LL could especially address the soft mechanisms of DG to secure the transparency, equity, and responsiveness of stakeholders. By implementing the principles of the LL, tradition-steering mechanisms and hierarchical structures could be broken up. This requires the long-term engagement of residents and the willingness to pursue openness in governance processes.

At the very least, the applied tools in both concepts are discussed. The LL can be considered as a meeting tool, which also involves knowledge transfer, communication, and cooperation. While governance tools are often only roughly defined, the explored LL tools are much more concrete and give the lab providers orientation on an operative level. However, through the flexibility and variety of LL tools, they should meet the conditions of DG, as long as the responsible persons are aware of the function of such tools and their technological requirements.

By reflecting the theoretical explanations of governance mechanisms, DG follows a flexible spectrum and mixture of different hard and soft factors that occur in practice. Each governance type represents an adoption of predominant network configurations and patterns of interaction [22,54]. This means that the suitability of the LL approach in DG also depends greatly on the existing structures and needs to be adopted carefully. In addition, the degree of self-organization can vary upon different destinations, which represents a mixture of institutional control and community involvement. Therefore, each destination needs to evaluate which stakeholders have which interests and to what degree and in what processes is residents' participation relevant. Those decisions determine which approaches should be applied: Community involvement is a loose way of sharing issues with residents or the community attachment, which is based on very emotional and individual links to the residents. Moreover, DG needs to redefine its borders and to critically assess the need to include urban planning or additional community groups in its processes [5,30]. For assisting a possible shift in local governance, the concepts of empowerment and planning can be worth recognizing [136]. Especially when considering sustainable development, community-driven and innovation-driven concepts are needed $[12,13]$.

\section{Conclusions and Research Recommendations}

This paper aimed at exploring the characteristics and mechanisms of the LL in order to discuss those in the context of DG. By the help of a systematic literature review (SLR), two research questions were tackled: (1) What are the characteristics and mechanisms of Living Labs (LLs)? and (2) How can the LL be utilized to promote the participation of residents in the context of destination governance (DG)? 
To answer the first research question, we conducted an SLR by including 40 papers that issued an LL within the last 10 years. The SLR led to a systematic definition of an LL, application fields and scales, targets and motives, principles, and applied tools. Therefore, this analysis has defined a wide frame of potentials that an LL delivers. To summarize those characteristics, an LL can be described as a flexible tool and as a space for discussing, testing, and experimenting issues and innovation with a broad set of stakeholders. In order to discuss the LL approach in the context of DG, the second research questions ask for the commonalities and dichotomies of the LL for DG. Due to a research gap, studies so far have only proven the suitability of the LL for governance in general [134] but lacks a structured transfer to destinations. To answer this research question, based on our SLR and an elaboration on DG, we can conclude that certain characteristics of the LL are crucial for such a transfer to DG (Figure 7). Such factors are a starting point for the following future research aims:

- $\quad$ strengthening of a joint city and destination planning;

- clarifying who is responsible for initiating and operating the LL and balancing guidelines and self-organization; exploring a differentiation of specific groups of residents and their interests, which is further based on the boundaries between local space and destination;

- balancing the interests of business-oriented stakeholders and community-driven stakeholders;

- strengthening the potential of DG to support innovation, which can provide new approaches to cope with overtourism;

- softening or breaking away from tradition hierarchies and processes to utilize the strengths of the LL in order to go beyond a mere coordinative approach;

- $\quad$ securing long-term engagement of the community in order to implement participation as a step-wise concept;

- $\quad$ exploring the variety of LL tools and their technological and infrastructural requirements so that an adequate adoption can be secured.

In addition, implementation in DG requires case-by-case consideration. This is also supported by manifold case studies that have been conducted in LL research. Within the LL setting, additional research on LL can focus on special target groups during the implementation of participatory plans. Second, based on residents' attachment, more research is needed on how to motivate different stakeholders to actively engage in planning processes [144]. Third, observations of LL processes could help in understanding the barriers to residents' participation and possible improvements. The LL, as a mediator [150], can include residents in discussions on overtourism. By practical means, such an approach could create the proposed measures to cope with overtourism, namely, "make residents benefit from the visitor economy", "create city experiences that benefit both visitors and local residents," "improve city infrastructure and facilities," or "communicating with and involving local stakeholders" [30]. A central challenge for those aims is the different perceptions of locals on overtourism. Although monitoring systems are requested [161], the perception of overtourism remains subjective and holds a spectrum between two extremes: One extreme might be destinations 'off the beaten track'; the other is where the weight of growing and seemingly excessive tourist demand are threatening the locals [6]. Within these extremes, a number of forms that influence residents' perceptions are prevalent, depending on the "number of tourists, their characteristics, and their spatial and temporal distribution" [162]. Under the heading of seasonality, the United Nations' World Tourism Organization (UNWTO) recommends the integration of tourism development into urban planning [30], as there still exists a gap in planning and community involvement [6,163]. For such planning processes, this perception of negative, but also positive effects from tourism [164] might decide about the attitude to engage and participate in such initiatives. A widespread tool to structure the attitude of residents is proposed by Doxey's irritation index, which maps the changing perceptions or residents against the background of the touristic life cycle. The words 'irritation' and 'antagonism' might reflect the existence of overtourism [165]. Scholars so far mostly agree that tourism per se is not the problem, but rather the implementation of management principles and good governance to 
balance benefits and to keep negative impacts at an acceptable level [6]. Therefore, issues such as managing the "satisfaction of local residents and/ or visitors" or the mitigation of negative perception of residents are crucial for further planning [161]. Beyond those tools, research and practice need to recognize further reaction strategies of locals, which could include recovering city centers as a local space (residentialization) $[165,166]$. Depending on the form of governance, residents can gain decision-making power, a consulting role, or other roles, as introduced by Arnstein [10]. We seek to motivate public authorities to start a process of residents' participation within the setting of an LL, as this, through the implementation of innovative tools and the breakup of established stakeholder structures and decision-making processes, can motivate and empower residents. However, a number of challenges should be recognized, such as the drop-out of participants before completing a certain task [145], the need to find the right balance between openness and closeness [143], project timeframes, the degree of documentation and information [106], and the effort to keep the LL alive [142].

This paper contributes to the discussion of residents' participation in DG through exploring the tool of LL. The LL has been analyzed through the increasingly recognized methodology of an SLR and its qualitative facets. As an outcome of the SLR and the related discussion on commonalities and dichotomies between the LL and DG, this paper provides only a starting point and an orientation for future research. Our contribution is limited by the range of an SLR and the selected criteria. Therefore, this paper fails to explore the details and function of every factor and every tool. Some qualitative criteria for SLRs [119] should help to evaluate the conducted research.

- The gap in LL research has been stated clearly, and the paper contributes to an overview of current LL research by recognizing former reviews.

- Moreover, the SLR provides practical evidence for LL operators or destination managers, as well as for researchers (Section 6).

- Central criteria for a good SLR are transparency and reproducibility, which were achieved in Section 3. Besides further bibliometric analysis, the procedures of reviewing the criteria, such as the principles, tools, or target groups of the LL, are transparent. Additional research documentation allows for transparency on the questions of which articles have been included or excluded.

- The SLR is limited by the focus on LL, while the DG is only described through a narrative literature review.

- The conducted SLR involved quantitative and qualitative analyses based on the research questions. The structure of Section 4 follows the SLR from a broad overview on the research field towards details in the characteristics of the LL. The findings were further synthesized through the matching with the DG in Section 5.

Author Contributions: Conceptualization: H.P. and H.T.; methodology: H.T., H.P., and N.O.; software: H.T. and N.O.; validation: H.T.; formal analysis: H.T. and N.O.; investigation: H.T., H.P., N.O., and A.S.; resources: H.P.; data curation: H.T.; writing—original draft preparation: H.T. and N.O.; writing—review and editing: H.P. and A.S.; visualization: H.T.; supervision: H.P. and A.S.; project administration: H.P. and H.T.; funding acquisition: H.P. and H.T. All authors have read and agreed to the published version of the manuscript.

Funding: This work was supported by the German Research Foundation (DFG) within the funding program Open Access Publishing.

Conflicts of Interest: The authors declare no conflict of interest. The funders had no role in the design of the study; in the collection, analyses, or interpretation of data; in the writing of the manuscript; or in the decision to publish the results.

\section{References}

1. Pechlaner, H.; Innerhofer, E.; Erschbamer, G. (Eds.) Overtourism: Tourism Management and Solutions; Routledge: Abingdon, UK, 2019; ISBN 0429582609.

2. McKinsey \& Company; World Travel \& Tourism Council. Coping with Success_Managing Overcrowding in Tourism Destinations; McKinsey \& Company: New York, NY, USA; World Travel \& Tourism Council: London, UK, 2017. 
3. Judd, D.R. The Infrastructure of Play: Building the Tourist City; Routledge: Abingdon, UK, 2015; ISBN 1315699583.

4. Swarbrooke, J. Sustainable Tourism Management; CABI: Wallingford, UK, 2011; ISBN 9780851993140.

5. Koens, K.; Postma, A.; Papp, B. Is Overtourism Overused? Understanding the Impact of Tourism in a City Context. Sustainability 2018, 10, 4384. [CrossRef]

6. Cheer, J.M.; Milano, C.; Novelli, M. Afterword: Over Overtourism or Just the Beginning? In Overtourism: Excesses, Discontents and Measures in Travel and Tourism; Milano, C., Cheer, J.M., Novelli, M., Eds.; CABI: Wallingford, UK; Boston, MA, USA, 2019; pp. 227-232, ISBN 9781786399823.

7. Zacher, D.; Pechlaner, H.; Olbrich, N. Strategy is the art of combining short- and long-term measures-Empirical evidence on "overtourism" from European cities and regions. In Overtourism: Tourism Management and Solutions; Pechlaner, H., Innerhofer, E., Erschbamer, G., Eds.; Routledge: Abingdon, UK, 2019; pp. 25-42, ISBN 0429582609.

8. Tosun, C. Towards a Typology of Community Participation in the Tourism Development Process. Anatolia 1999, 10, 113-134. [CrossRef]

9. Tosun, C. Limits to community participation in the tourism development process in developing countries. Tour. Manag. 2000, 21, 613-633. [CrossRef]

10. Arnstein, S.R. A Ladder Of Citizen Participation. J. Am. Inst. Plan. 1969, 35, 216-224. [CrossRef]

11. Brager, G.; Specht, H.; Torczyner, J.L. Community Organizing, 2nd ed.; Columbia University Press: New York, NY, USA, 1987; ISBN 0231054629.

12. Lenao, M.; Saarinen, J. Integrated rural tourism as a tool for community tourism development: Exploring culture and heritage projects in the North-East District of Botswana. S. Afr. Geogr. J. 2015, 97, 203-216. [CrossRef]

13. Moscardo, G. (Ed.) Building Community Capacity for Tourism Development; CABI: Wallingford, UK; Cambridge, MA, USA, 2008; ISBN 9781845934477.

14. Beritelli, P. Cooperation among prominent actors in a tourist destination. Ann. Tour. Res. 2011, 38, 607-629. [CrossRef]

15. Schuppert, G.F. (Ed.) Governance-Forschung: Vergewisserung über Stand und Entwicklungslinien, 2nd ed.; Nomos-Verl.-Ges.: Baden, Germany, 2006; ISBN 9783832921491.

16. Raich, F. Governance räumlicher Wettbewerbseinheiten: Ein Ansatz für die Tourismus-Destination; Deutsher Universitäts-Verlag: Wiesbaden, Germany; GWV Fachverlage GmbH: Wiesbaden, Germany, 2006; ISBN 3835005995.

17. Pechlaner, H.; Kozak, M.; Volgger, M. Destination leadership: A new paradigm for tourist destinations? Tour. Rev. 2014, 69, 1-10. [CrossRef]

18. Offe, C. Governance- “Empty Signifier” Oder Sozialwissenschaftliches Forschungsprogramm? In Governance in Einer Sich Wandelnden Welt, 1st ed.; Schuppert, G.F., Zürn, M., Eds.; VS Verlag für Sozialwissenschaften: Wiesbaden, Germany, 2008; pp. 61-76, ISBN 3531159224.

19. Volgger, M.; Pechlaner, H.; Pichler, S. The practice of destination governance: A comparative analysis of key dimensions and underlying concepts. J. Tour. Herit. Serv. Mark. 2017, 3, 18-24.

20. Beritelli, P.; Bieger, T. From destination governance to destination leadership—Defining and exploring the significance with the help of a systemic perspective. Tour. Rev. 2014, 69, 25-46. [CrossRef]

21. Amore, A.; Hall, C.M. From governance to meta-governance in tourism? Re-incorporating politics, interests and values in the analysis of tourism governance. Tour. Recreat. Res. 2016, 1-14. [CrossRef]

22. Gereffi, G.; Humphrey, J.; Sturgeon, T. The governance of global value chains. Rev. Int. Political Econ. 2005, 12, 78-104. [CrossRef]

23. Bouchon, F.; Rauscher, M. Cities and tourism, a love and hate story; towards a conceptual framework for urban overtourism management. Int. J. Tour. Cities 2019, 5, 598-619. [CrossRef]

24. Sanoff, H. Community Participation Methods in Design and Planning; Wiley: New York, NY, USA, 2000; ISBN 9780471355458.

25. Guimont, D.; Lapointe, D. Empowering Local Tourism Providers to Innovate through a Living Lab Process: Does Scale Matter? Technol. Innov. Manag. Rev. 2016, 6, 18-25. [CrossRef]

26. De Jager, L.; Buitendag, A.A.K.; van der Walt, J.S. Presenting a framework for knowledge management within a web-enabled Living Lab. S. Afr. J. Inf. Manag. 2012, 14. [CrossRef] 
27. Vilariño, F.; Karatzas, D. The Library Living Lab: A Collaborative Innovation Model for Public Libraries. Technol. Innov. Manag. Rev. 2018, 8, 17-25. [CrossRef]

28. Nonaka, 1.; Takeuchi, H.; Umemoto, K. A theory of organizational knowledge creation. IJTM 1996, 11, 833-845.

29. Popadiuk, S.; Choo, C.W. Innovation and knowledge creation: How are these concepts related? Int. J. Inf. Manag. 2006, 26, 302-312. [CrossRef]

30. World Tourism Organization (UNWTO). 'Overtourism'?-Understanding and Managing Urban Tourism Growth beyond Perceptions; Executive Summary; UNWTO: Madrid, Spain, 2018; ISBN 9789284420070.

31. Bramwell, B.; Lane, B. Critical research on the governance of tourism and sustainability. J. Sustain. Tour. 2011, 19, 411-421. [CrossRef]

32. Benedetto, G.; Carboni, D.; Corinto, G.L. Governance of Sustainable Tourism in a Vast Area Surrounding a National Park. Procedia Environ. Sci. 2016, 32, 38-48. [CrossRef]

33. Moscardo, G.; Benckendorff, P. (Eds.) Education for Sustainability in Tourism: A handbook of Processes, Resources, and Strategies, 1st ed.; Springer: Heidelberg, Germany, 2015; ISBN 9783662474693.

34. Patterson, J.; Schulz, K.; Vervoort, J.; van der Hel, S.; Widerberg, O.; Adler, C.; Hurlbert, M.; Anderton, K.; Sethi, M.; Barau, A. Exploring the governance and politics of transformations towards sustainability. Environ. Innov. Soc. Transit. 2017, 24, 1-16. [CrossRef]

35. Scuttari, A.; Volgger, M.; Pechlaner, H. Transition management towards sustainable mobility in Alpine destinations: Realities and realpolitik in Italy's South Tyrol region. J. Sustain. Tour. 2016, 24, 463-483. [CrossRef]

36. Page, S.J.; Yeoman, I.; Connell, J.; Greenwood, C. Scenario planning as a tool to understand uncertainty in tourism: The example of transport and tourism in Scotland in 2025. Curr. Issues Tour. 2010, 13, 99-137. [CrossRef]

37. Boström, M.; Jönsson, A.M.; Lockie, S.; Mol, A.P.J.; Oosterveer, P. Sustainable and responsible supply chain governance: Challenges and opportunities. J. Clean. Prod. 2015, 107, 1-7. [CrossRef]

38. Dörry;, S. Globale Wertschöpfungsketten im Tourismus: Ohnmächtige Unternehmen in mächtiger Position? Relationale Governance bei der Organisation deutscher Pauschalreisen nach Jordanien; LIT: Berlin, Germany; Münster, Germany, 2008; ISBN 978-3-8258-1845-6.

39. Sanderson, J. Risk, uncertainty and governance in megaprojects: A critical discussion of alternative explanations. Int. J. Proj. Manag. 2012, 30, 432-443. [CrossRef]

40. Kallmuenzer, A.; Kraus, S.; Peters, M.; Steiner, J.; Cheng, C.-F. Entrepreneurship in tourism firms: A mixed-methods analysis of performance driver configurations. Tour. Manag. 2019, 74, 319-330. [CrossRef]

41. Minnaert, L. Social tourism participation: The role of tourism inexperience and uncertainty. Tour. Manag. 2014, 40, 282-289. [CrossRef]

42. Pechlaner, H. (Ed.) Destination und Lebensraum. Perspektiven Touristischer Entwicklung; Springer Fachmedien Wiesbaden GmbH: Wiesbaden, Germany, 2019; ISBN 978-3-658-28109-0.

43. Pechlaner, H.; Zacher, D.; Eckert, C.; Petersik, L. Joint responsibility and understanding of resilience from a DMO perspective-An analysis of different situations in Bavarian tourism destinations. Int. J. Tour. Cities 2019, 5, 146-168. [CrossRef]

44. Ruhanen, L.; Scott, N.; Ritchie, B.; Tkaczynski, A. Governance: A review and synthesis of the literature. Tour. Rev. 2010, 65, 4-16. [CrossRef]

45. Halkier, H. Innovation and Destination Governance in Denmark: Tourism, Policy Networks and Spatial Development. Eur. Plan. Stud. 2014, 22, 1659-1670. [CrossRef]

46. Beaumont, N.; Dredge, D. Local tourism governance: A comparison of three network approaches. J. Sustain. Tour. 2010, 18, 7-28. [CrossRef]

47. Abbott, J. Community participation and its relationship to Community Development. Community Dev. J. 1995, 30, 158-168. [CrossRef]

48. Moscardo, G. The Role of Knowledge in Good Governance for Tourism. In Tourist Destination Governance: Practice, Theory and Issues; Laws, E., Agrusa, J.F., Richins, H., Eds.; CAB International: Cambridge, MA, USA, 2011; pp. 67-82, ISBN 9781845937942.

49. Jordan, E.J.; Vogt, C.A.; Kruger, L.E.; Grewe, N. The interplay of governance, power and citizen participation in community tourism planning. J. Policy Res. Tour. Leis. Events 2013, 5, 270-288. [CrossRef] 
50. Rydin, Y.; Pennington, M. Public participation and local environmental planning: The collective action problem and the potential of social capital. Local Environ. 2000, 5, 153-169. [CrossRef]

51. Hemmati, M. (Ed.) Multi-Stakeholder Processes for Governance and Sustainability: Beyond Deadlock and Conflict; Routledge: Abingdon, UK, 2012; ISBN 1136560858.

52. Bramwell, B. Participative planning and governance for sustainable tourism. Tour. Recreat. Res. 2010, 35, 239-249. [CrossRef]

53. Volgger, M.; Pechlaner, H. Requirements for destination management organizations in destination governance: Understanding DMO success. Tour. Manag. 2014, 41, 64-75. [CrossRef]

54. World Tourism Organization. A Practical Guide to Tourism Destination Management; World Tourism Organization: Madrid, Spain, 2007; ISBN 978-92-844-1243-3.

55. Flagestad, A.; Hope, C. Strategic success in winter sports destinations: A sustainable valuecreation perspective. Tour. Manag. 2001, 2001, 445-461. [CrossRef]

56. Pechlaner, H.; Bachinger, M. Knowledge networks of innovative businesses: An explorative study in the region of Ingolstadt. Serv. Ind. J. 2010, 30, 1737-1756. [CrossRef]

57. Fürst, D. Regional Governance zwischen Wohlfahrtsstaat und neoliberaler Marktwirtschaft. In Demokratien in Europa; Katenhusen, I., Lamping, W., Eds.; Springer: Wiesbaden, Germany, 2003; pp. 251-268.

58. Ness, H.; Haugland, S.A.; Aarstad, J. Interfirm resource integration in destination contexts. Curr. Issues Tour. 2019, 1-16. [CrossRef]

59. Strobl, A.; Peters, M. Entrepreneurial reputation in destination networks. Ann. Tour. Res. 2013, 40, 59-82. [CrossRef]

60. Freeman, R.E. Strategic Management: A Stakeholder Approach; Cambridge University Press: Cambridge, UK, 2010; ISBN 9780521151740.

61. Schuhbert, A. "Coopetition” und Innovation in touristischen Destinationen: Das Beispiel der Provinz Napo (Ecuador). tw Z. Für Tour. 2014, 6, 73-78.

62. Komppula, R. The role of different stakeholders in destination development. Tour. Rev. 2016, 71, 67-76. [CrossRef]

63. Presenza, A.; Cipollina, M. Analysing tourism stakeholders networks. Tour. Rev. 2010, 65, 17-30. [CrossRef]

64. Timur, S.; Getz, D. A network perspective on managing stakeholders for sustainable urban tourism. Int. J. Contemp. Hosp. Manag. 2008, 20, 445-461. [CrossRef]

65. Franch, M.; Martini, U.; Buffa, F. Roles and opinions of primary and secondary stakeholders within community-type destinations. Tour. Rev. 2010, 65, 74-85. [CrossRef]

66. Gettkant, A. Nachbarn in einer Welt: Der Bericht der Kommission für Weltordnungspolitik; SEF: Bonn, Germany, 1995; ISBN 9783927626324.

67. Della Corte, V.; Gaudio, G.D.; Iavazzi, A. Leadership in Destination Management: Its Implications in a Systemic Approach. JMS 2014, 4. [CrossRef]

68. Governance von Destinationen. Neue Ansätze für die Erfolgreiche Steuerung Touristischer Zielgebiete; Saretzki, A., Wöhler, K., Eds.; Erich Schmidt: Berlin, Germany, 2013; ISBN 9783503154517.

69. Graham, J.; Amos, B.; Plumptre, T.W. Governance Principles for Protected Areas in the 21st Century; Institute on Governance, Governance Principles for Protected Areas: Ottawa, ON, Canada, 2003.

70. Ritchie, B.J.R.; Crouch, G.I. Competitive Destination: A Sustainable Tourism Perspective, 2nd ed.; CABI Publishing: Wallingford, UK; Cambridge, MA, USA, 2005; ISBN 184593010X.

71. Wang, Y.; Pizam, A. (Eds.) Destination Marketing and Management: Theories and Applications; CABI: Cambridge, MA, USA, 2011; ISBN 1845937007.

72. Vargas-Sánchez, A.; Oom do Valle, P.; da Costa Mendes, J.; Silva, J.A. Residents' attitude and level of destination development: An international comparison. Tour. Manag. 2015, 48, 199-210. [CrossRef]

73. Nunkoo, R.; Smith, S.L.J.; Ramkissoon, H. Residents' attitudes to tourism: A longitudinal study of 140 articles from 1984 to 2010. J. Sustain. Tour. 2013, 21, 5-25. [CrossRef]

74. Sheng, L.; Li, T.; Wang, J. Tourism and externalities in an urban context: Theoretical model and empirical evidence. Cities 2017, 70, 40-45. [CrossRef]

75. Nunkoo, R.; Ramkissoon, H. Residents' Satisfaction with Community Attributes and Support for Tourism. J. Hosp. Tour. Res. 2011, 35, 171-190. [CrossRef]

76. Mansfeld, J.; Jonas, A. Evaluating the socio-cultural carrying capacity of rural tourism communities: A 'value stretch' approach. Tijdschr. voor Econ. en Soc. Geogr. 2006, 97, 583-601. [CrossRef] 
77. Correia, A.; Kozak, M.; Gnoth, J.; Fyall, A. (Eds.) Co-Creation and Well-Being in Tourism; Springer International Publishing: Cham, Switzerland, 2017; ISBN 9783319441078.

78. Buonincontri, P.; Morvillo, A.; Okumus, F.; van Niekerk, M. Managing the experience co-creation process in tourism destinations: Empirical findings from Naples. Tour. Manag. 2017, 62, 264-277. [CrossRef]

79. Prebensen, N.K.; Chen, J.S.; Uysal, M. Co-creation of Tourist Experience: Scope, Defi nition and Structure. In Creating Experience Value in Tourism; First Paperback Edition; Prebensen, N.K., Chen, J., Uysal, M., Eds.; CABI: Wallingford, Germany, 2016; pp. 1-9, ISBN 978-1786390301.

80. Nunkoo, R.; Gursoy, D. Residents' support for tourism. Ann. Tour. Res. 2012, 39, 243-268. [CrossRef]

81. Herntrei, M. Wettbewerbsfähigkeit von Tourismusdestinationen: Bürgerbeteiligung als Erfolgsfaktor? Springer Fachmedien Wiesbaden: Wiesbaden, Germany, 2014; ISBN 978-3-658-07675-7.

82. Boley, B.B.; McGehee, N.G.; Perdue, R.R.; Long, P. Empowerment and resident attitudes toward tourism: Strengthening the theoretical foundation through a Weberian lens. Ann. Tour. Res. 2014, 49, 33-50. [CrossRef]

83. Volo, S. Comity or Conflict? A Qualitative Study on Host-Guest Relationship in Second Home Tourism. Tour. Anal. 2011, 16, 443-460. [CrossRef]

84. Haobin Ye, B.; Qiu Zhang, H.; Huawen Shen, J.; Goh, C. Does social identity affect residents' attitude toward tourism development? Int. J. Contemp. Hosp. Menag. 2014, 26, 907-929. [CrossRef]

85. Ap, J. Residents' perceptions research on the social impacts of tourism. Ann. Tour. Res. 1990, 17, 610-616. [CrossRef]

86. Woosnam, K.M.; Norman, W.C.; Ying, T. Exploring the Theoretical Framework of Emotional Solidarity between Residents and Tourists. J. Travel Res. 2009, 48, 245-258. [CrossRef]

87. Stylidis, D.; Biran, A.; Sit, J.; Szivas, E.M. Residents' support for tourism development: The role of residents' place image and perceived tourism impacts. Tour. Manag. 2014, 45, 260-274. [CrossRef]

88. Lee, T.H. Influence analysis of community resident support for sustainable tourism development. Tour. Manag. 2013, 34, 37-46. [CrossRef]

89. Laskey, A.B.; Nicholls, W. Jumping Off the Ladder. J. Am. Plan. Assoc. 2019, 85, 348-362. [CrossRef]

90. McCool, S.F.; Martin, S.R. Community Attachment and Attitudes Toward Tourism Development. J. Travel Res. 2016, 32, 29-34. [CrossRef]

91. Czernek, K. Tourism features as determinants of knowledge transfer in the process of tourist cooperation. Curr. Issues Tour. 2014, 20, 204-220. [CrossRef]

92. Weidenfeld, A.; Williams, A.M.; Butler, R.W. Knowledge transfer and innovation among attractions. Ann. Tour. Res. 2010, 37, 604-626. [CrossRef]

93. Jamal, T.; Getz, D. Community roundtables for tourism-related conflicts: The dialectics of consensus and process structures. J. Sustain. Tour. 1999, 7, 290-313. [CrossRef]

94. Simmons, D.G. Community participation in tourism planning. Tour. Manag. 1994, 15, 98-108. [CrossRef]

95. Manente, M.; Minghetti, V.; Mingotto, E. Responsible Tourism and CSR: Assessment Systems for Sustainable Development of SMEs in Tourism; Springer International Publishing: Cham, Switzerland, 2014; ISBN 978-3-319-06307-2.

96. Walker, K.; Moscardo, G. Controversial Ecotourism and Stakeholder Roles in Governance: 'Swim with Humpback Whales' in Vava'u. In Tourist Destination Governance: Practice, Theory and Issues; Laws, E., Agrusa, J.F., Richins, H., Eds.; CAB International: Cambridge, MA, USA, 2011; pp. 103-116, ISBN 978-1-84593-794-2.

97. Scott, N.; Baggio, R.; Cooper, C. (Eds.) Network Analysis and Tourism-From Theory to Practice; Channel View Publications: Clevedon, UK, 2008.

98. Laws, E.; Agrusa, J.F.; Richins, H. (Eds.) Tourist Destination Governance: Practice, Theory and Issues; CAB International: Cambridge, MA, USA, 2011; ISBN 978-1-84593-794-2.

99. Scott, N.; Baggio, R.; Cooper, C. Tourism destination networks and knowledge transfer. In Network Analysis and Tourism-From Theory to Practice; Scott, N., Baggio, R., Cooper, C., Eds.; Channel View Publications: Clevedon, UK, 2008; pp. 40-57.

100. Choibamroong, T. A Stakeholder Approach for Sustainable Community-Based Rural Tourism Development in Thailand. In Tourist Destination Governance: Practice, Theory and Issues; Laws, E., Agrusa, J.F., Richins, H., Eds.; CAB International: Cambridge, MA, USA, 2011; pp. 173-186, ISBN 978-1-84593-794-2.

101. Guzmán, J.G.; del Carpio, A.F.; Colomo-Palacios, R.; de Diego, M.V. Living Labs for User-Driven Innovation: A Process Reference Model. Res. Technol. Manag. 2015, 56, 29-39. [CrossRef] 
102. Brankaert, R.; den Ouden, E. The Design-Driven Living Lab: A New Approach to Exploring Solutions to Complex Societal Challenges. Technol. Innov. Manag. Rev. 2017, 7, 44-51. [CrossRef]

103. Sharp, D.; Salter, R. Direct Impacts of an Urban Living Lab from the Participants' Perspective: Livewell Yarra. Sustainability 2017, 9, 1699. [CrossRef]

104. Cosgrave, E.; Arbuthnot, K.; Tryfonas, T. Living Labs, Innovation Districts and Information Marketplaces: A Systems Approach for Smart Cities. Procedia Comput. Sci. 2013, 16, 668-677. [CrossRef]

105. Leminen, S. Coordination and Participation in Living Lab Networks. Technol. Innov. Manag. Rev. 2013, 3, 5-14. [CrossRef]

106. Nesti, G. Co-production for innovation: The urban living lab experience. Policy Soc. 2018, 37, 310-325. [CrossRef]

107. Calzada, I. Local entrepreneurship through a multistakeholders' tourism living lab in the post-violence/peripheral era in the Basque Country. Reg. Sci. Policy Pract. 2019, 11, 451-466. [CrossRef]

108. Jernsand, E.M. Student living labs as innovation arenas for sustainable tourism. Tour. Recreat. Res. 2019, 44, 337-347. [CrossRef]

109. Cooper, H.M. Organizing knowledge syntheses: A taxonomy of literature reviews. Knowl. Soc. 1988, 1, 104. [CrossRef]

110. Bensberg, F.; Auth, G.; Czarnecki, C. Einsatz von Text Analytics zur Unterstützung literaturintensiver Forschungsprozesse-Konzeption, Realisierung und Lessons Learned. Anwend. Und Konzepte Der Wirtsch. 2018, 8, 1-6.

111. Kitchenham, B. Procedures for Performing Systematic Reviews; Keele University: Keele, UK; National ICT Australia Ltd.: Eversleigh, Australia, 2004; pp. 1-26.

112. Carter, R.W.; Thok, S.; O’Rourke, V.; Pearce, T. Sustainable tourism and its use as a development strategy in Cambodia: a systematic literature review. J. Sustain. Tour. 2015, 23, 797-818. [CrossRef]

113. Petticrew, M.; Roberts, H. Systematic Reviews in the Social Sciences: A Practical Guide. Couns. Psychother. Res. 2006, 6, 304-305. [CrossRef]

114. Denyer, D.; Tranfield, D. Producing a systematic review. In The Sage Handbook of Organizational Research Methods; Buchanan, D.A., Bryman, A., Eds.; SAGE Publications Ltd.: New York, NY, USA, 2009; pp. 671-689.

115. Spasojevic, B.; Lohmann, G.; Scott, N. Air transport and tourism-A systematic literature review (2000-2014). Curr. Issues Tour. 2018, 21, 975-997. [CrossRef]

116. Warren, C.; Becken, S. Saving energy and water in tourist accommodation: A systematic literature review (1987-2015). Int. J. Tour. Res. 2017, 19, 289-303. [CrossRef]

117. Tranfield, D.; Denyer, D.; Smart, P. Towards a Methodology for Developing Evidence-Informed Management Knowledge by Means of Systematic Review. Br. J. Manag. 2003, 14, 207-222. [CrossRef]

118. Yang, E.C.L.; Khoo-Lattimore, C.; Arcodia, C. A systematic literature review of risk and gender research in tourism. Tour. Manag. 2017, 58, 89-100. [CrossRef]

119. Snyder, H. Literature review as a research methodology: An overview and guidelines. J. Bus. Res. 2019, 104, 333-339. [CrossRef]

120. Carrillat, F.A.; Legoux, R.; Hadida, A.L. Debates and assumptions about motion picture performance: A meta-analysis. J. Acad. Mark. Sci. 2018, 46, 273-299. [CrossRef]

121. Gjaltema, J.; Biesbroek, R.; Termeer, K. From government to governance ... to meta-governance: a systematic literature review. Public Manag. Rev. 2019, 10, 1-21. [CrossRef]

122. Gomezelj, D.O. A systematic review of research on innovation in hospitality and tourism. Int. J. Contemp. Hosp. Manag. 2016, 28, 516-558. [CrossRef]

123. Mariani, M.; Baggio, R.; Fuchs, M.; Höepken, W. Business intelligence and big data in hospitality and tourism: A systematic literature review. Int. J. Contemp. Hosp. Manag. 2018, 30, 3514-3554. [CrossRef]

124. Van der Zee, E.; Vanneste, D. Tourism networks unraveled: A review of the literature on networks in tourism management studies. Tour. Manag. Perspect. 2015, 15, 46-56. [CrossRef]

125. Sotiriadis, M.D. Sharing tourism experiences in social media. Int. J. Contemp. Hosp. Manag. 2017, 29 , $179-225$. [CrossRef]

126. Berrang-Ford, L.; Pearce, T.; Ford, J.D. Systematic review approaches for climate change adaptation research. Reg. Environ. Chang. 2015, 15, 755-769. [CrossRef]

127. Galvan, J.L.; Galvan, M.C. Writing Literature Reviews: A Guide for Students of the Social and Behavioral Sciences; Routledge: Abingdon, UK, 2017; ISBN 1351858920. 
128. Bortz, J.; Döring, N. Forschungsmethoden und Evaluation: Für Human- und Sozialwissenschaftler, 4th ed.; Springer-Medizin-Verlag: Heidelberg, Germany, 2009; ISBN 978-3-540-33305-0.

129. O'Neill, M.M.; Booth, S.R. N7 + 1 Literature Reviews, 2017; Legwork Consultancy.

130. O'Neill, M.M.; Sarah, R.; Lamb, J.T. Using NVivo ${ }^{\mathrm{TM}}$ for literature reviews: The eight step pedagogy $(\mathrm{N7}+1)$. Qual. Rep. 2018, 23, 21-39.

131. Jackson, K.; Bazeley, P. Qualitative Data Analysis with Nvivo; SAGE Publications Limited: New York, NY, USA, 2019; ISBN 1526478498.

132. QSR International Pty Lt. NVivo Qualitative Data Analysis Software. Available online: https://www. qsrinternational.com/nvivo/home (accessed on 11 November 2019).

133. Bulkeley, H.; Coenen, L.; Frantzeskaki, N.; Hartmann, C.; Kronsell, A.; Mai, L.; Marvin, S.; McCormick, K.; van Steenbergen, F.; Voytenko Palgan, Y. Urban living labs: Governing urban sustainability transitions. Curr. Opin. Environ. Sustain. 2016, 22, 13-17. [CrossRef]

134. Bulkeley, H.; Marvin, S.; Palgan, Y.V.; McCormick, K.; Breitfuss-Loidl, M.; Mai, L.; von Wirth, T.; Frantzeskaki, N. Urban living laboratories: Conducting the experimental city? Eur. Urban Reg. Stud. 2018, 26, 317-335. [CrossRef]

135. Engels, F.; Wentland, A.; Pfotenhauer, S.M. Testing future societies? Developing a framework for test beds and living labs as instruments of innovation governance. Res. Policy 2019, 48, 103826. [CrossRef]

136. Edwards-Schachter, M.E.; Matti, C.E.; Alcántara, E. Fostering Quality of Life through Social Innovation: A Living Lab Methodology Study Case. Rev. Policy Res. 2012, 29, 672-692. [CrossRef]

137. Issa, A.; Schumacher, S.; Hatiboglu, B.; Groß, E.; Bauernhansl, T. Open Innovation in the Workplace: Future Work Lab as a Living Lab. Procedia CIRP 2018, 72, 629-634. [CrossRef]

138. Veeckman, C.; van der Graaf, S. The City as Living Laboratory: Empowering Citizens with the Citadel Toolkit. Technol. Innov. Manag. Rev. 2015, 5, 6-17. [CrossRef]

139. Benabbas, A.; Elmamooz, G.; Lagesse, B.; Nicklas, D.; Schmid, U. Living Lab Bamberg: An infrastructure to explore smart city research challenges in the wild. Künstl Intell 2017, 31, 265-271. [CrossRef]

140. Steuer, S.; Benabbas, A.; Kasrin, N.; Nicklas, D. Challenges and Design Goals for an Architecture of a Privacy-preserving Smart City Lab. Datenbank Spektrum 2016, 16, 147-156. [CrossRef]

141. van der Walt, J.S.; Buitendag, A.A.; Zaaiman, J.J.; van Vuuren, J.J. Community Living Lab as a Collaborative Innovation Environment. IISIT 2009, 6, 421-436. [CrossRef]

142. Mulder, I. Living Labbing the Rotterdam Way: Co-Creation as an Enabler for Urban Innovation. Technol. Innov. Manag. Rev. 2012, 2, 39-43. [CrossRef]

143. Budweg, S.; Schaffers, H.; Ruland, R.; Kristensen, K.; Prinz, W. Enhancing collaboration in communities of professionals using a Living Lab approach. Prod. Plan. Control 2011, 22, 594-609. [CrossRef]

144. Leminen, S.; Rajahonka, M.; Westerlund, M. Towards Third-Generation Living Lab Networks in Cities. Technol. Innov. Manag. Rev. 2017, 7, 21-35. [CrossRef]

145. Habibipour, A.; Georges, A.; Ståhlbröst, A.; Schuurman, D.; Bergvall-Kåreborn, B. A Taxonomy of Factors Influencing Drop-Out Behaviour in Living Lab Field Tests. Technol. Innov. Manag. Rev. 2018, 8, 5-21. [CrossRef]

146. Mastelic, J.; Sahakian, M.; Bonazzi, R. How to keep a living lab alive? Info Digit. Policy Regul. Gov. 2015, 17, 12-25. [CrossRef]

147. Schuurman, D.; de Marez, L.; Ballon, P. Open Innovation Processes in Living Lab Innovation Systems: Insights from the LeYLab. Technol. Innov. Manag. Rev. 2013, 3, 28-36. [CrossRef]

148. Alam, M.; Porras, J. Architecting and Designing Sustainable Smart City Services in a Living Lab Environment. Technologies 2018, 6, 99. [CrossRef]

149. Burbridge, M. If Living Labs are the Answer-What's the Question? A Review of the Literature. Procedia Eng. 2017, 180, 1725-1732. [CrossRef]

150. Ståhlbröst, A. A Living Lab as a Service: Creating Value for Micro-enterprises through Collaboration and Innovation. Technol. Innov. Manag. Rev. 2013, 3, 37-42. [CrossRef]

151. Vicini, S.; Bellini, S.; Sanna, A. The City of the Future Living Lab. AUSMT 2012, 2, 201-208. [CrossRef]

152. Pucihar, A.; Zajc, I.; Sernec, R.; Lenart, G. Living Lab as an Ecosystem for Development, Demonstration and Assessment of Autonomous Mobility Solutions. Sustainability 2019, 11, 4095. [CrossRef]

153. Dell'Era, C.; Landoni, P. Living Lab: A Methodology between User-Centred Design and Participatory Design. Creat. Innov. Manag. 2014, 23, 137-154. [CrossRef] 
154. Veeckman, C.; Schuurman, D.; Leminen, S.; Westerlund, M. Linking Living Lab Characteristics and Their Outcomes: Towards a Conceptual Framework. Technol. Innov. Manag. Rev. 2013, 3, 6-15. [CrossRef]

155. Lin, W.-Y.; Lin, C.-T.; Wang, Y.-H.; Chen, R.-T. The Transformation of Users in Living Lab Construction: The Case of Eco-City Living Lab. AUSMT 2012, 2, 231-240. [CrossRef]

156. Kareborn, B.B.; Stahlbrost, A. Living Lab: An open and citizen-centric approach for innovation. IJIRD 2009, 1, 356. [CrossRef]

157. Westerlund, M.; Leminen, S.; Rajahonka, M. A Topic Modelling Analysis of Living Labs Research. Technol. Innov. Manag. Rev. 2018, 8, 40-51. [CrossRef]

158. Canzler, W.; Engels, F.; Rogge, J.-C.; Simon, D.; Wentland, A. From "living lab" to strategic action field: Bringing together energy, mobility, and Information Technology in Germany. Energy Res. Soc. Sci. 2017, 27, 25-35. [CrossRef]

159. Liedtke, C.; Welfens, M.J.; Rohn, H.; Nordmann, J. LIVING LAB: User-driven innovation for sustainability. Int. J. Sustain. High. Educ. 2012, 13, 106-118. [CrossRef]

160. Coenen, T.; van der Graaf, S.; Walravens, N. Firing Up the City-A Smart City Living Lab Methodology. Interdiscip. Stud. J. 2014, 3, 118-129.

161. Kuščer, K.; Mihalič, T. Residents' Attitudes towards Overtourism from the Perspective of Tourism Impacts and Cooperation-The Case of Ljubljana. Sustainability 2019, 11, 1823. [CrossRef]

162. Namberger, P.; Jackisch, S.; Schmude, J.; Karl, M. Overcrowding, Overtourism and Local Level Disturbance: How Much Can Munich Handle? Tour. Plan. Dev. 2019, 16, 452-472. [CrossRef]

163. Jóhannesson, G.T.; Lund, K.A. Beyond Overtourism: Studying the Entanglements of Society and Tourism in Iceland. In Overtourism: Excesses, Discontents and Measures in Travel and Tourism; Milano, C., Cheer, J.M., Novelli, M., Eds.; CABI: Wallingford, UK; Boston, MA, USA, 2019; pp. 91-106, ISBN 9781786399823.

164. Muler Gonzalez, V.; Coromina, L.; Galí, N. Overtourism: Residents' perceptions of tourism impact as an indicator of resident social carrying capacity-Case study of a Spanish heritage town. Tour. Rev. 2018, 73, 277-296. [CrossRef]

165. Hospers, G.-J. Overtourism in European Cities: From Challenges to Coping Strategies. CESifo Forum 2019, 11, 1907. [CrossRef]

166. Bacová, A.; Puškár, B.; Vráblová, E. Residentialization of Public Spaces: Bratislava Example. IOP Conf. Ser. Mater. Sci. Eng. 2017, 245, 42012. [CrossRef]

(C) 2020 by the authors. Licensee MDPI, Basel, Switzerland. This article is an open access article distributed under the terms and conditions of the Creative Commons Attribution (CC BY) license (http://creativecommons.org/licenses/by/4.0/). 